\title{
Analisis Strategi Keunggulan Kompetitif Berkelanjutan Perusahaan Crowd Business Syariah (Studi Kasus pada Halal Network International)
}

\section{Strategic Analysis of Sustainable Competitive Advantage for Sharia Crowd Business Firm (Case Study on Halal Network International)}

\author{
Amirah Firas Mufidah ${ }^{1}$, Laily Dwi Arsyianti ${ }^{2}$ Ibdalsyah $^{3}$ \\ ${ }^{1}$ Sekolah Bisnis, Institut Pertanian Bogor, Jalan Raya Pajajaran, Bogor 16128, Indonesia, \\ amirahfirasmufidah@gmail.com \\ ${ }^{2}$ Fakultas Ekonomi dan Manajemen, Institut Pertanian Bogor, Jalan Raya Dramaga, Bogor 16680, Indonesia, \\ arsyianti@apps.ipb.ac.id \\ ${ }^{3}$ Sekolah Bisnis, Institut Pertanian Bogor, Jalan Raya Pajajaran, Bogor 16128, Indonesia, \\ buyaibdalsyah@gmail.com
}

\begin{abstract}
Business model innovation of a company is a form of adaptation to the current economic turmoil to determine competitive advantage. To deal with this, PT HPA Indonesia or Halal Network International (HNI) which is based on the Muslim crowd and consistently is considered to be developing and getting the leading position must be able to survive in the middle of challenging market. The purpose of this research is to analyze the strategy of sustainable competitive advantage for HNI as sharia crowd business firm. The mixed method approach was carried out using literature studies, guided interviews, and online questionnaires for certain experts. The data processing technique used in this research is ANP (Analytical Network Process) to involve the analysis of the relationship between the network elements. The results of this research indicate that effective strategy is the right strategy for sustainable competitive performance. This strategy focuses on developing resource capital. The three elements with the lowest priority in this pride strategy model are reputation \& quality control, technology \& buyer fulfillment and sales of product content. By combining institutional capital and resource capital, a sustainable competitive advantage can be achieved by focusing performance on the subfactors of corporate image and leadership.
\end{abstract}

Keywords: Analytic Network Process, effective strategy, sharia crowd business, sustainable competitive advantage.

\begin{abstract}
Abstrak. Inovasi model bisnis suatu perusahaan merupakan bentuk adaptasi terhadap gejolak ekonomi saat ini untuk menentukan keunggulan kompetitif. Untuk menghadapi hal ini, PT HPA Indonesia atau Halal Network International (HNI) yang berbasis Muslim crowd dan dianggap konsisten berkembang serta mendapatkan leading position harus mampu bertahan di tengah kondisi pasar saat ini. Penelitian ini bertujuan untuk menganalisis strategi keunggulan kompetitif yang berkelanjutan pada HNI sebagai perusahaan crowd business syariah. Pendekatan metode campuran (mixed method) dilakukan dengan menggunakan studi pustaka, wawancara terpandu dan kuesioner online untuk pakar tertentu. Teknik pengolahan data yang digunakan dalam penelitian ini adalah ANP (Analytic Network Process) untuk melibatkan analisis hubungan antarjaringan unsur. Hasil penelitian menunjukkan bahwa effective strategy adalah strategi kinerja yang tepat untuk mencapai keunggulan kompetitif berkelanjutan pada crowd business syariah. Tiga unsur dengan prioritas terendah pada model strategi keunggulan berkelanjutan ini yaitu reputasi dan kontrol kualitas, teknologi dan pemenuhan pembeli serta penjualan konten produk. Dengan mengkombinasikan modal institusional dan sumberdaya, keunggulan kompetitif yang berkelanjutan dapat dicapai dengan memprioritaskan kinerja pada unsur citra perusahaan dan kepemimpinan.
\end{abstract}

Kata kunci: Analytic Network Process, crowd business syariah, keunggulan kompetitif berkelanjutan, strategi efektif. 


\section{PENDAHULUAN}

\section{Latar Belakang}

Perkembangan kompetisi bisnis dan gejolak ekonomi menuntut entitas usaha untuk memiliki inovasi dan strategi yang mampu memiliki daya saing. Hal inilah yang kemudian dengan sendirinya membuat suatu entitas bisnis menciptakan keunggulan kompetitif dengan mengubah model bisnis yang mereka terapkan dan memicu adanya multiplier perubahan-perubahan dalam perkembangan ekonomi saat ini (Magretta, 2002). Sebagaimana model Kotler, market leader merupakan pemain yang mapan dan sulit untuk dikalahkan. Namun fenomena tersebut tidak lagi relevan menurut Markides dan Charitou (2004). Saat ini relatif banyak market challenger yang berhasil mengalahkan market leader dengan menggunakan model bisnis yang berbeda.

Sementara menurut Marjanovic et al. (2012), hal ini dapat terjadi karena adanya open innovation yang menantang cara-cara tradisional dengan melakukan perpindahan kreativitas dan 'pemikiran out-of-the box' bahkan dalam organisasi yang paling progresif sekalipun. Dijelaskan pula cara melakukan open innovation melalui tiga metode yaitu dengan open source, outsourcing atau crowdsourcing. Berdasarkan studi empiris yang dilakukan Lüttgens et al. (2014), pendekatan tournament crowdsourcing terbukti efektif menciptakan komitmen dan kontribusi crowd dalam usaha perusahaan melakukan open innovation serta kapabilitas promotor yang mampu mengalokasikan peran dengan tepat. Dengan berfokus untuk mendapatkan dan mempertahankan faktor - faktor keunggulan kompetitif ini, perusahaan dengan model crowdsourcing dapat dikonfirmasi mampu menopang kelangsungan bisnis di pasar yang sangat kompetitif.

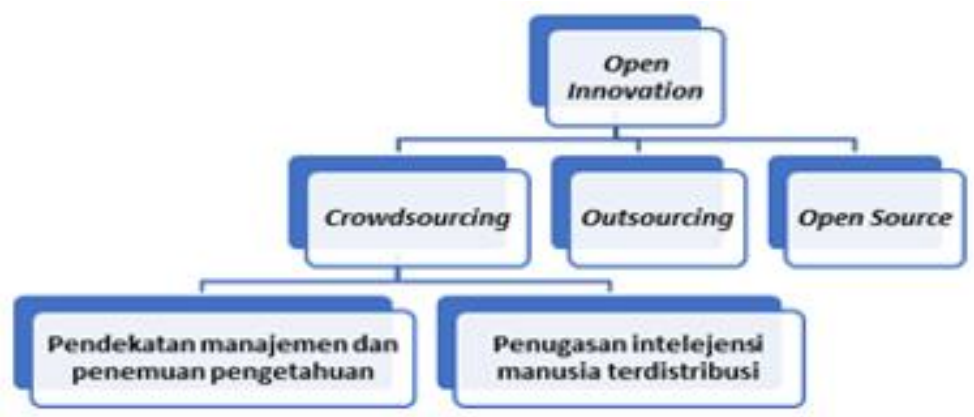

Sumber : Marjanovic, et.al., 2012

Gambar 1 Perbedaan tipe open innovation

Dalam Quran surat Shaad ayat 24 disebutkan bahwa manusia diperintahkan untuk tidak berbuat zalim dalam berserikat. Kemudian, dalam Quran surat Al-Maidah ayat 2, saling bekerjasama (ta 'awun) juga diwajibkan dalam hal kebaikan dan ketakwaan. Sehingga, bentuk kerjasama bisnis atau syirkah perlu dimodifikasi dan dikembangkan dalam koridor syariah agar memiliki daya saing dan kemapanan (Yarmunida, 2014). Berdasarkan Hoque et al. (2018), Islamic enterprises perlu dikembangkan, dibentuk dan dikelola sesuai dengan pedoman Quran dan sunah, sehingga diharapkan dapat bersaing dan berkembang secara berkelanjutan.

Muslim crowd di Indonesia merupakan penduduk Muslim yang terbesar di dunia yaitu sekitar $13 \%$. Dengan kata lain, ada sekitar 229 juta Muslim atau $87.2 \%$ dari 263 juta populasi penduduk di Indonesia (World Population Review, 2020). Menurut Chairul Tanjung (2020) dalam Sidang Pleno ke-8 KUII VII, pengusaha Muslim di Indonesia harus membangun usaha dari kita, oleh kita dan untuk kita dengan memperbanyak pengusaha dan berserikat (Anam, 2020).

Di era pandemi di mana banyak terjadi ketidakpastian dan gejolak ekonomi, belum banyak pengusaha Muslim yang melakukan shifting terhadap model bisnisnya. Shifting dapat dilakukan dengan cara 
mengembangkan inovasi dan strategi bisnis dengan melakukan crowdsourcing untuk menciptakan core competence dan meningkatkan sustainable competitive advantage. Hal ini dapat dilihat dari 105 crowd business yang terdaftar di Asosiasi Penjualan Langsung Indonesia (APLI), hanya 7 yang saat ini masih memegang sertifikat DSN MUI aktif, serta hanya 2 perusahaan milik Muslim lokal, yaitu PT Herba Penawar Alwahida Indonesia (HNI) dan PT Arminareka Pharmasia Pratama (Armina Daily). Bagaimanapun, pengusaha Muslim yang melakukan bisnis kolaborasi dan melakukan inovasi secara terbuka sudah mulai bermunculan dalam bentuk model taksonomi lain seperti crowdfunding syariah, product \& content sales komoditas emas sebagai bentuk investasi yang dianggap lebih syar' $i$, kemudian reseller pada crowd bisnis model taksonomi lainnya.

Model bisnis PT Herba Penawar Alwahida Indonesia atau yang biasa dikenal HNI (Halal Network International) memanfaatkan kolaborasi Muslim crowd untuk memasarkan produknya dan membuka inovasi pemasaran yang dimonitor dalam sebuah kantor virtual. Hal tersebut dapat menghasilkan individu promotor yang berkomitmen, berkontribusi dan memiliki kredibilitas yang baik dalam membina individu promotor lainnya.

HNI merupakan sebuah lini bisnis internasional yang menyediakan produk halal bagi Muslim yang dapat dipercaya dengan adanya para individu manajemen yang berintegritas dalam mengawal bahan maupun vendor dari pengembangan produk yang dimilikinya. Sejak tiga tahun terakhir, pengembangan strategi branding HNI dilakukan dengan mengklaim dirinya sebagai halal network. Hal tersebut dilakukan sebagai strategi kompetitif untuk menjadikan HNI sebagai sebuah bisnis bersama dalam menyediakan, mengkampanyekan dan menguasai pasar dengan produk halal berupa health food and beverage (makanan dan minuman sehat harian), body and home care (kebutuhan perawatan diri harian) dan herbs sunah dan unggul (kebutuhan kesehatan harian).

Secara legalitas kesyariahan, HNI termasuk Perusahaan Penjualan Langsung Berjenjang Syariah (PLBS) atau biasa dikenal sebagai MLM atau multi-level marketing (selanjutnya disebut network marketing) berbasis syariah berdasarkan SK.No.014.71.01/DSN-MUI/XII/2018. Sebagai salah satu bisnis network marketing yang berkembang pesat, HNI perlu mempertahankan keunggulan kompetitifnya sehingga dapat bersaing dan terus mengembangkan bisnisnya secara berkelanjutan.

\section{Perumusan Masalah}

Keterancaman positioning HNI sebagai market leader crowd business syariah memerlukan strategi yang mapan untuk dapat bertahan di gejolak ekonomi saat ini. Pentingnya berserikat dan profesional disertai peluang berupa Muslim crowd yang luas, memerlukan adanya sebuah model bisnis bersama yang mapan, sesuai nilai syar'i, berdaya saing untuk menjawab tantangan industri 4.0, dan berkelanjutan untuk menunjang kesejahteraan dan kejayaan perekonomian umat.

Secara khusus, ketegasan dibutuhkan dalam sistem halal network karena citra ini menjadi solusi atas perspektif negatif terhadap sebuah multi-level marketing (MLM) di masyarakat umum sekaligus modal terpenting dalam keunggulan kompetitif sebagaimana penelitian Keong dan Dastane (2019). Selain itu, kesadaran kesehatan yang terus meningkat menyebabkan banyak masyarakat Muslim memerlukan herbal halal yang berkualitas yang sesuai sunah dan multiguna, namun belum dipasarkan dengan tuntas kepada Muslim crowd untuk menumbuhkan keloyalan customer dan calon customer atas munculnya produk-produk kesehatan lainnya. Ditemukan bahwa dengan benchmark, kemampuan pemasaran dapat terus berkembang untuk keunggulan kompetitif yang berkelanjutan (Vorhies dan Morgan, 2005). Sehingga halal network merupakan model crowd business syariah yang masih perlu dikembangkan untuk mencapai keunggulan kompetitif yang berkelanjutan.

Dengan demikian, rumusan permasalahan yang perlu dikaji dalam penelitian ini adalah sebagai berikut:

1. Apa saja strategi yang memengaruhi model crowd business syariah sehingga mampu menghadapi peluang dan tantangan bisnis?

2. Apa strategi yang menentukan keunggulan kompetitif pada perusahaan crowd business syariah?

AL-MUZARA'AH Vol. 9 No. 1, 2021 
3. Strategi apa saja yang menjadi prioritas dalam pengembangan crowd business syariah untuk mencapai keunggulan kompetitif yang berkelanjutan?

\section{Tujuan Penelitian}

Berdasarkan latar belakang dan permasalahan yang telah dijelaskan di atas maka tujuan dari penelitian ini adalah sebagai berikut:

1. Mengidentifikasi strategi yang memengaruhi model crowd business syariah sehingga mampu menghadapi peluang dan tantangan bisnis.

2. Mengidentifikasi strategi yang menentukan keunggulan kompetitif pada perusahaan berbasis crowd business syariah.

3. Menganalisis strategi yang menjadi prioritas dalam pengembangan crowd business syariah untuk mencapai keunggulan kompetitif yang berkelanjutan.

\section{Ruang Lingkup dan Kebaruan Penelitian}

Secara terminologi, model crowd business syariah yang dimaksud dalam penelitian ini adalah model bisnis bersama menggunakan inovasi terbuka yang menjunjung tinggi prinsip dan nilai-nilai syariah dalam aktivitas muamalah. Penelitian ini mengaplikasikan model tersebut kepada HNI yang nampak melakukan pergeseran posisi strategi menggunakan open innovation, yaitu halal network. Model crowd business digunakan secara bergantian dengan crowdsourcing. Belum banyak literatur dan publikasi akademik yang membahas tentang taksonomi model crowd business secara spesifik, sehingga dalam penentuan indikasi dan strategi akan banyak menggunakan literatur crowdsourcing yang saat ini jauh lebih dulu dikembangkan dan banyak digunakan. Begitu juga dengan model crowd business syariah, sehingga hal ini menjadi kebaruan dari penelitian ini.

\section{TINJAUAN PUSTAKA}

\section{Manajemen Strategi}

David dan David (2016) memaparkan bahwa manajemen strategi merupakan sebuah seni atau keilmuan untuk memformulasikan, mengimplementasikan dan mengevaluasi sebuah keputusan cross-functional (antardivisi) untuk mencapai tujuannya dengan mengintegrasi seluruh divisi yang ada. Secara konteks dan praktik, manajemen strategi digunakan untuk meninjau sebuah kinerja kompetitif sebuah entitas usaha dalam meningkatkan, mempertahankan dan menjadikannya sebuah keunggulan kompetitif yang berkelanjutan. Karakteristik dari keunggulan kompetitif yaitu jarang di industri, sedikit diimitasi oleh kompetitor dan sulit disubstitusi.

Hafeez et al. (2002) berpendapat bahwa posisi kompetitif sebuah entitas usaha terdiri dari persebaran atau tindakan strategi berupa sumber daya, kapabilitas dan kompetensi yang dimiliki suatu entitas bisnis. Sumber daya sebuah perusahaan mencakup sumber daya fisik (peralatan, bahan mentah, gedung, dsb), sumber daya manusia atau intelektual (pelatihan, pengalaman, skill, dsb) dan sumber daya organisasi atau kultural (reputasi, proses, prosedural, birokrasi, dsb). Sementara itu, kapabilitas sebuah perusahaan merupakan hasil elaborasi yang dihasilkan dari sumber daya yang dimiliki. Kemudian, sekumpulan kapabilitas berharga yang menciptakan suatu keunikan pada sebuah entitas bisnis ini yang disebut core competence. Sehingga dapat disimpulkan bahwa keunggulan kompetitif merupakan hal yang dihasilkan dari rangkaian tersebut yang dipatenkan suatu perusahaan menjadi sebuah posisi strategi bisnis. Perusahaan yang sudah mengetahui siklus hidup produknya di antara empat posisi kompetitif berdasarkan model Kotler dan Kellar, baru bisa menentukan strategi (pemasaran) kompetitif bisnis di masa depan (Sumarwan, 2017).

\section{Keunggulan Kompetitif Berkelanjutan}

Keong dan Dastane (2019) membahas faktor-faktor yang berkontribusi terhadap keunggulan kompetitif berkelanjutan untuk perusahaan multi-level marketing di Malaysia. Dengan metode kuantitatif, 48 
sebanyak 398 data sampel dikumpulkan menggunakan teknik judgement. Pengujian normalitas dan reliabilitas dilakukan bersama confirmatory factory analysis yang diikuti dengan analisis varian. Dilakukan estimasi nilai maximum likelihood untuk menilai konsistensi internal, validitas konvergen dan diskriminan dengan teknik Structural Equation Model. Variabel yang ditentukan dalam penelitian ini adalah company image, product innovation, leadership, distributor reward system, dan distributor training system.

Ahmad et al. (2012) menyatakan bahwa branding kepemimpinan pada UKM antarregional ekonomi dapat berimplikasi pada zona ekonomi lainnya di mana personalitas pemimpin dapat menjadi prediktor praktik branding dan keterlibatan konsumen yang berkesinambungan. Sarif (2019) menemukan bahwa sustainable competitive advantage di antara UMKM di masyarakat Muslim dapat dicapai dengan ta'awun (cooperation) strategis yang dilanjutkan dengan kompetisi yang baik (fastabiqul khairat). Dalam model strategi kompetitif, kinerja dapat diukur dengan karakter, proses kerja dan outcome dengan metode fuzzy ANP (Mirahmadi et al., 2018). Omer (2014) menyatakan bahwa konsep keberlanjutan dan arsitektur Islam merupakan satu kesatuan karena pentingnya prinsip-prinsip Islam tentang manusia, alam, kehidupan, keluasan, dan universalitas tujuan (syariat) Islam. Terakhir, sustainable Muslim society dapat dicapai dengan pemaparan ajaran Islam dengan bingkai yang positif (lembut) (Hussin et al., 2017).

Dari penelitian Keong dan Dastane (2019), citra perusahaan dapat dianggap sebagai variabel terpenting untuk keuntungan berkelanjutan perusahaan network marketing. Kepemimpinan memengaruhi positif keunggulan berkelanjutan karena para pemimpin berada pada posisi paling berpengaruh untuk mengarahkan kesuksesan perusahaan. Pada industri ini, distributor adalah tenaga penjualan utama perusahaan dan pelatihan serta pertemuan yang relevan diperlukan untuk meningkatkan tingkat keberhasilan penjualan produk. Perusahaan networking terbesar dunia seperti Amway, Herbalife dan Young Living, berhasil meningkatkan market share melalui inovasi produk. Sebagai tambahan, untuk mengidentifikasi, membangun dan mengembangkan kemampuan pemasaran perlu dilakukan dengan mekanisme pembelajaran benchmark. Sebagai alat manajemen, benchmark digunakan secara luas oleh organisasi berbasis pasar sebagai trayek menuju keunggulan kompetitif yang berkelanjutan (Vorhies dan Morgan 2005).

Hasil penelitian Oliver (1997) menunjukkan bahwa perusahaan membutuhkan resource capital dan institutional capital untuk mencapai keunggulan kompetitif yang berkelanjutan. Resource capital diartikan sebagai sumber daya dan kapasitas perusahaan yang menambahkan nilai seperti saluran distribusi, kompetensi terpaten dan talent management. Sedangkan institutional capital merupakan faktor - faktor kontekstual yang meninggikan penggunaan optimal resource capital, misalnya budaya continuous improvement, knowledge sharing antarorganisasi dan sistem teknologi informasi. Adapun kunci sukses masing-masing modal yakni dengan pengadaan dan perlindungan atas sumber daya langka yang tidak dapat ditiru (resource capital) dan manajemen yang efektif atas konteks pemanfaatan sumber daya (institutional capital).

Berdasarkan Oliver (1997), Hafeez et al. (2002), Vorhies dan Morgan (2005), David dan David (2016), Keong dan Dastane (2019), dapat disimpulkan bahwa faktor yang memengaruhi sustainable strategi cenderung terhadap efektivitas manajemen dibanding efisiensi manajemen. Sebaliknya, menurut Morioka et al. (2017) efisiensi manajemen penting untuk keberlangsungan keunggulan kompetitif.

\section{Crowd Business (Crowdsourcing) sebagai Inovasi Terbuka}

Marjanovic et al. (2012) mendefinisikan inovasi terbuka sebagai inovasi yang dapat diakses secara bebas oleh semua melalui informasi publik. Inovasi terbuka merupakan paradigma tentang sebuah sebuah perusahan yang membuka inovasi dan R\&D yang dimilikinya seiring dengan perkembangan faktor internal dan eksternal bahkan akses menuju pasar yang saat ini sudah menuntut hadirnya sebuah inovasi teknologi online (Chesbrough, 2003). 
Sementara menurut Henkel (2006), dalam kemajuan teknologi saat ini inovasi terbuka dapat berbentuk pengembangan bisnis kolaborasi, tetapi tanpa jaminan kontrak untuk mendapatkannya. Penelitian Ali et al. (2015) memaparkan tentang mobile platform untuk manajemen kerumunan haji dalam layanan komunikasi dan file sharing sebagai (inovasi) SmartCrowd. Haseeb et al. (2019) menyatakan bahwa tantangan sosial dan teknologi memainkan peran utama dalam meningkatkan keunggulan kompetitif berkelanjutan di mana keselarasan strategis adalah kunci dalam mencerminkan peran positif keduanya.

Suatu perusahaan perlu berinvestasi pada sumber daya internalnya untuk membuktikan bahwa inovasi terbuka dari proyek crowdsourcing akan sukses dan dapat menyelesaikan tantangan secara otomatis (Lüttgens et al. 2014). Pertama, kunci sukses crowdsourcing ialah peran kontributor atau promotor yang memiliki komitmen, kontribusi dan kemampuan lebih. Kedua, penerapan crowdsourcing sebagai inovasi terbuka perlu mengidentifikasi calon kontributor atau promotor yang tepat dan mengalokasikannya sedini mungkin dengan didukung pemberian insentif. Kontributor atau promotor didorong untuk menemukan promotor lainnya yang mau bekerja sama untuk menemukan orang-orang andal lainnya yang termotivasi (promotor) dari jaringan kerja (network) di bawahnya yang disebut network marketing. Dan ketiga, power promotor juga diharuskan untuk menawarkan kesempatan kepada promotor ahli sebagai saluran distribusinya (distribution channel).

Boudreau dan Lakhani (2013) berpendapat bahwa untuk memanfaatkan inovasi secara optimal agar tidak menghilangkan peluang besar, seorang manajer harus mengetahui dengan jelas keuntungan dan cara mengelola crowd-busines. Adapun pendekatan mengelola crowd business dipaparkan dalam Tabel 1 berikut:

Tabel 1 Pendekatan mengelola crowd business

\begin{tabular}{cll}
\hline Pendekatan & \multicolumn{1}{c}{ Uraian cara } & Contoh \\
\hline Contest & $\begin{array}{l}\text { Menciptakan tantangan dengan teknis, analisis dan ilmiah yang Kontes Design } \\
\text { tinggi disertai imbal hasil besar untuk menghasilkan solusi bernilai } \\
\text { dan kompleksitas tinggi, terhadap masalah independen berskala } \\
\text { besar dan beragam. }\end{array}$ & Situs Wikis \\
Collaborative & $\begin{array}{l}\text { Menyederhanakan sebuah proyek, meluaskan pembagian tugas dan } \\
\text { memfasilitasi koordinasi dengan teknologi untuk menghasilkan nilai } \\
\text { besar dengan gabungan sejumlah kontributor yang beragam. }\end{array}$ & $\begin{array}{c}\text { aplikasi } \\
\text { iTunes } \\
\text { Complementors }\end{array}$ \\
\hline inti untuk menghasilkan sebuah solusi yang beragam terhadap \\
produk atau jasa inti.
\end{tabular}

Sumber : Boudreau dan Lakhani, 2013

\section{Monetisasi Model Crowd Business (Crowdsourcing)}

Berdasarkan Dawson dan Bynghail (2012), crowd business merupakan sebuah model bisnis yang secara fundamental didasarkan pada kontribusi orang banyak ( rowd) sebagai sumber utama penciptaan nilai dalam proses bisnis tersebut. Model crowd business semakin hari semakin berkembang untuk meningkatkan keunggulan dan kesuksesan jangka panjang untuk mengakomodir perusahaan menciptakan nilai baru. Terdapat tujuh taksonomi model crowd business utama yang pada dasarnya memiliki kesamaan mendasar dalam mengagregasi sumber daya (crowd) yang dimiliki untuk menciptakan nilai yang dapat diuangkan. 
Monetisasi pada model bisnis keramaian tergantung pada jenis model crowd business. Ada berbagai pendekatan berbeda untuk monetisasi yang dapat diterapkan dengan gambaran sebagai berikut:

Tabel 2 Jenis-jenis monetisasi crowd business

\begin{tabular}{cl}
\hline Jenis Model & \multicolumn{1}{c}{ Penerapan Monetisasi } \\
\hline Transaction fees & $\begin{array}{l}\text { Pada crowd platform mencakup biaya posting pekerjaan, biaya penawaran dan } \\
\text { komisi pembayaran. }\end{array}$ \\
\hline Membership fees & $\begin{array}{l}\text { Biaya yang dibayarkan oleh klien dan/atau penyedia layanan untuk berpartisipasi } \\
\text { dalam platform, layanan atau model penciptaan nilai. }\end{array}$ \\
\hline Test fees & Bernilai tinggi karena tes menjadi penting bagi penyedia untuk potensi buyer. \\
\hline Licensing & Lisensi platform crowd dapat dilisensikan untuk instalasi perusahaan. \\
\hline Pay per task & Dapat didasarkan pada tugas/layanan yang jelas terdefinisi untuk klien. \\
\hline Product sales & Menjadi sumber pendapatan utama jika produk-produk dirancang oleh crowd. \\
\hline Advertising & Dari model berbasis konten dapat dihasilkan terutama dari iklan di media. \\
\hline Subscription & Dapat ditetapkan perangkat lunak untuk akses ke konten bernilai tinggi. \\
\hline Content sales & Potongan konten yang dikemas dapat dijual dalam berbagai format. \\
\hline Packaged services & Layanan yang jelas dengan harga tetap dapat dikirimkan oleh banyak orang. \\
\hline Custom services & $\begin{array}{l}\text { Layanan khusus dipesan lebih dahulu untuk disampaikan kepada orang banyak, } \\
\text { dengan perusahaan bertindak sebagai antarmuka ke klien akhir. }\end{array}$ \\
\hline
\end{tabular}

Sumber : Dawson dan Bynghail, 2012

\section{Unsur Keberhasilan Model Crowd Business}

Dawson dan Bynghail (2012) memaparkan tiga karakter unsur penting untuk keberhasilan dalam menerapkan model bisnis berdasarkan crowd. Pada dasarnya kedua sisi jaringan ini perlu dikembangkan secara bersamaan, kecuali jika sudah ada kumpulan sebelumnya dari bisnis yang sudah mapan. Pertama, crowd business pada umumnya bergantung pada banyaknya kontributor yang berkualitas dan meluas. Kemudian pembeli yang luas dan berkualitas juga menjadi penting dalam crowd services. Ketika hanya ada satu klien, karakteristiknya akan menyeleksi penyedia layanan terbaik. Terakhir yakni berbagai kemampuan yang memberikan pondasi sukses bagi model bisnis crowd.

Model crowd business dianggap menarik karena model bisnis ini secara inheren dapat dengan mudah diskalakan. Pada saat terdapat banyak cara untuk menghasilkan pendapatan dengan cepat, pemberian layanan dapat diskalakan dengan sangat cepat dan luas dengan desain yang baik. Namun terdapat dua kendala potensial terhadap skalabilitas pada model crowd business yang perlu dipahami dan dikelola secara efektif untuk penskalaan cepat.

Pertama, bagi layanan berbasis kerumunan, pengiriman layanan terbatas pada tiga hal, yaitu kontrol kualitas, manajemen proyek dan ketersediaan bakat penyedia. Kedua yakni tantangan dalam menghasilkan pendapatan tergantung penawaran yang ditentukan dengan tepat dan sumber pendapatan yang berkembang sesuai pasar. Tujuan pembangunan berkelanjutan di mana perusahaan dan crowd berkontribusi besar di dalamnya, merupakan fitur pengembangan awal di negara Muslim. Berdasarkan prinsip Islam, kebijakan penguasa perlu dikombinasikan dengan pandangan ulama sebagai paradigma perkembangan berkelanjutan (Gallant, 2009). Pengembangan crowd (rakyat) harus berupa 
pemberdayaaan, peningkatan produktivitas, penghentian penggusuran dan harus mengubah posisi poor crowd menjadi aset pembangunan di jangka panjang (Swasono, 2005).

\section{Muslim Crowd dan Model Halal Network (Crowd Business Syariah)}

Crowdfunding syariah berpotensi menjadi inovasi keuangan berikutnya dalam industri keuangan Islam, karena masih dalam tahap awal perkembangan (Achsien dan Purnamasari, 2016). Meskipun crowdfunding di pasar Muslim relatif masih baru, tetapi laju peluncuran platform baru menunjukkan bahwa perubahan mendasar sedang berlangsung. Hoque et al. (2018) menemukan bahwa prospek pengembangan social enterprise melalui crowdfunding sangat cerah karena memiliki inspirasi agama serta memiliki potensi donor, pemberi pinjaman dan investor yang besar di dunia Muslim. Masyarakat umum di negara-negara Muslim memiliki pandangan baik terhadap usaha sosial yang memungkinkan social enterprise dapat menciptakan permintaan yang baik sehingga berhasil membuat kesetaraan sosial dalam masyarakat Muslim. Menurut Yusanto dan Widjajakusuma (2002), orientasi bisnis Muslim tidak hanya pada materi tapi juga pada kemanusiaan, akhlak dan ruhiyah. Usaha sosial Islami ini terbukti meningkatkan pengembangan ekonomi dan sosial (Arshad et al., 2015).

Hoque et al. (2018) juga menekankan bahwa social enterprise dapat bersaing dengan business enterprise dan menjadi katalisator bagi perekonomian dengan modifikasi model crowdfunding sebelumnya menjadi model yang berbeda (donation base, reward base, qardee hasana/ interest fee loan base, equity base). Yakni model crowdfunding dalam perspektif Islam yang dibentuk dan dikelola sesuai dengan pedoman Quran dan sunah. Di sisi lain, pemerintah juga didorong untuk maju dalam menggalakkan dukungan kebijakan demi perkembangan dan percepatan enterprise dengan model baru ini.

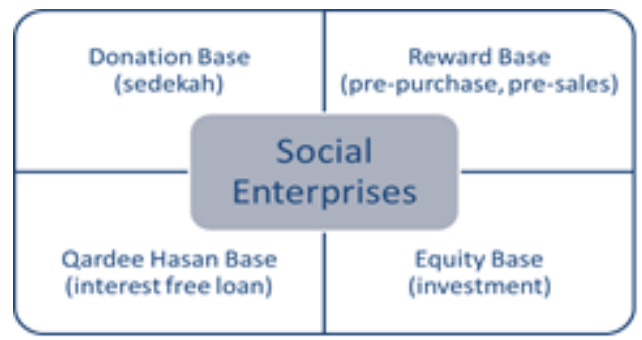

Sumber : Hoque et al., 2018

Gambar 2 Basis Muslim crowdfunding dan kontribusinya

Menurut Firly (2017), kunci utama dalam halal network adalah model bisnis yang fokus terhadap pemberdayaan umat (Muslim crowd) pada umumnya dan keluarga Muslim pada khususnya, dengan tujuan untuk membangun kekuatan ekonomi dan menciptakan peluang bisnis dengan pola bisnis network marketing syariah. Dengan kata lain, halal network adalah membangun jejaring pasar besar produk halal di Asia dan dunia, dengan 'amal jama'i (kerjasama) mulai dari menyediakan, mengkampanyekan dan menguasai jalur distribusinya. Di sini, Muslim crowd melakukan konsumsi sekaligus investasi atas kesehatan dan ekonomi serta pengembangan kapasitas diri dan keluarganya. Selain itu, bentuk kerjasama bisnis atau syirkah dimodifikasi agar berdaya saing serta tetap berada dalam koridor syariah (Yarmunida, 2014).

\section{Kerangka Pemikiran Penelitian}

Kerangka penelitian diawali dengan mengkaji keunggulan kompetitif HNI dalam menghadapi peluang dan tantangan bisnisnya. Selanjutnya keunggulan kompetitif yang telah didefinisikan sebagai 'kondisi eksisting' dielaborasi dengan unsur-unsur yang menentukan keunggulan kompetitif network marketing. Kemudian, studi ini akan menganalisis tentang unsur strategi yang terlibat dalam inovasi model bisnis HNI untuk meninjau model bisnis crowd business berbasis syariah. Sehingga sektor industri serupa bisa 
mengadopsi strategi ini dan turut mengembangkan crowd business syariah sebagai sebuah inovasi menggunakan Muslim crowd untuk bersama-sama membangun kejayaan perekonomian Islam.

Pembobotan unsur didapatkan melalui pengolahan nilai perbandingan melalui kuesioner yang disebarkan kepada para pakar yang sama pada tahap guided interview. Perbandingan antarunsur juga mempertimbangkan hubungan antarjaringan (Analytic Network Process) menggunakan perbandingan berpasangan (pairwise comparison) dengan menggunakan penilaian 9 point scale system metode ANP untuk menghasilkan prioritas.

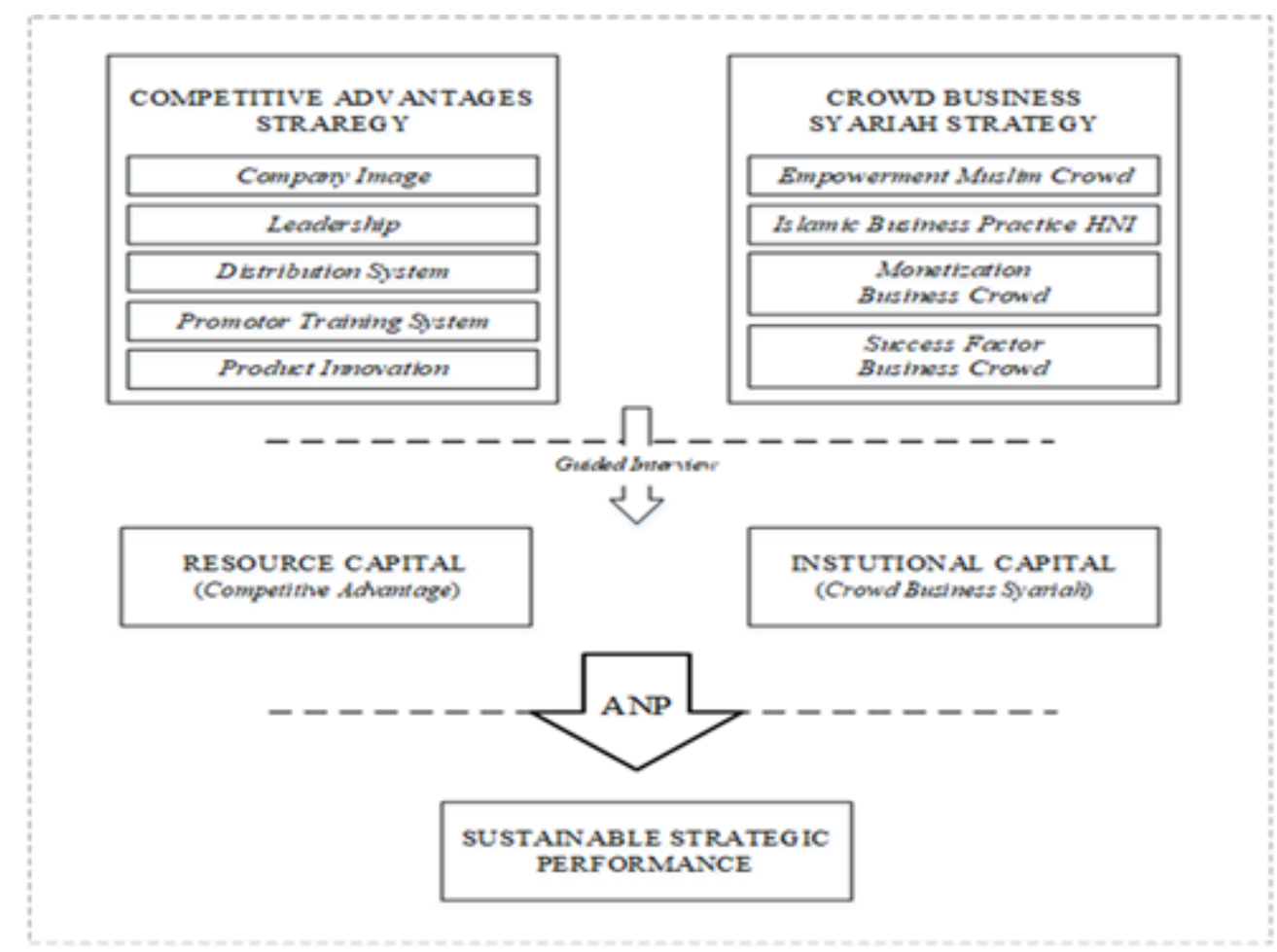

Sumber : Ilustrasi penulis, 2020

Gambar 3 Kerangka pemikiran penelitian

\section{METODE}

\section{Lokasi dan Waktu Penelitian}

Pengumpulan dan pengolahan data primer baik berupa wawancara dan data lainnya dilakukan di Indonesia dari bulan Februari 2020 hingga Oktober 2020.

\section{Jenis dan Sumber Data}

\section{Data primer}

Penelitian menggunakan guided interview pada beberapa key informant yang memiliki fungsi strategis dalam mengembangkan dan menjalankan corporate business plan HNI meliputi direktur marketing, komisaris dan dewan pengawas serta beberapa key promotor yang memiliki peran signifikan dalam mensukseskan model bisnis ini. Dalam penelitian ini juga dilakukan pengambilan data perbandingan berpasangan dari 5 orang ahli. Dalam kuesioner juga diobservasi instrumen teknologi yang dianggap sebagai salah satu keunggulan kompetitif yang menjadikan HNI sebagai crowd business syariah. 


\section{Data sekunder}

Penelitian ini juga mengutip hasil studi literatur seperti jurnal, buku, internet dan kepustakaan lainnya (panduan, buletin bulanan, dokumentasi seminar dan workshop) seperti dwilogi TMB to be the best market leader, materi pelatihan dan sebagainya. Seluruh data yang terkait dengan hal-hal yang dibahas dalam penelitian ini digunakan untuk membantu menjawab pertanyaan penelitian dan hipotesis, serta untuk memahami data primer secara lebih mendalam.

\section{Kriteria Narasumber dan Responden Ahli}

Narasumber dalam penelitian ini dipilih berdasarkan pengetahuan, pengalaman dan otoritas dalam fungsi promosi bisnis crowd business syariah, manajemen perusahaan, dan akademisi. Terdapat juga pengutipan pandangan APLI sebagai asosiasi yang dipercaya Kementerian Perdagangan dalam menyeleksi dan meregulasi perusahaan network marketing yang beredar di Indonesia. Keempat narasumber setidaknya sudah berpengalaman selama lebih dari 8 tahun dalam fungsinya masingmasing. Bahkan narasumber promotor dan manajemen perusahaan sudah lebih dari 10 tahun terlibat dalam network marketing HPA, sebelum bertransformasi menjadi HNI HPAI.

Untuk responden ahli ditentukan 5 orang yang paling memahami konteks pertanyaan yang dimaksud dalam penelitian ini. Kelima orang tersebut selain dianggap paling mengetahui tentang kinerja crowd business syariah, mayoritas dari mereka juga sudah ikut terlibat dalam sistem bisnis perusahaan sejak awal berdiri. Tiga orang promotor yang menjadi responden ahli juga merupakan salah satu pendiri perusahaan yang hingga saat ini diakui sebagai top leader (kontributor besar) dalam capaian perusahaan. Ketiga ahli ini diharapkan dapat memberikan gambaran komprehensif tentang pengembangan crowd business syariah sebagai pelaku, sedangkan akademisi dan pengawas syariah berfungsi sebagai pengawas kepatuhan terhadap konsep dan model.

\section{Pendekatan dan Metode Penelitian}

Penelitian ini menggunakan gabungan pendekatan metode campuran (mixed method). Studi literatur dilakukan untuk menentukan unsur-unsur apa saja yang menentukan strategi kompetitif berkelanjutan. Unsur-unsur tersebut dikonfirmasi dengan hasil wawancara terpandu dari narasumber.

\section{Guided Interview}

Guided interview melibatkan pengembangan serangkaian pertanyaan dan format umum yang diikuti dan digunakan kepada semua narasumber. Walaupun struktur umumnya sama untuk semua individu yang diwawancarai, pewawancara dapat memvariasikan pertanyaan sesuai dengan situasi yang dialami. Metode ini dilakukan untuk menggali informasi tentang kondisi eksisting terkait keunggulan kompetitif HNI. Informasi tersebut untuk memastikan bahwa hasil studi literatur dapat diterapkan pada kondisi eksisting model bisnis HNI yaitu halal network. Kunci strategi akan ditanyakan kepada para pakar sebagai dasar pengembangan kriteria kunci strategi model crowd business syariah.

\section{Analytic Network Process (ANP)}

ANP merupakan metode untuk memberikan solusi dalam suatu situasi yang kompleks yang memerlukan beberapa keputusan alternatif yang komprehensif (Yüksel dan Dagdeviren, 2007). Metode ini dikembangkan dan digunakan untuk mengevaluasi strategi logistik dan supplier, mengoptimalkan dan meningkatkan kecepatan proses produksi, menyeleksi interdependensi dalam sebuah proyek sistem informasi, mengevaluasi alternatif proyek hingga mampu memperkirakan krisis keuangan dalam proses bisnis. ANP mampu menangani umpan balik untuk memilih alternatif tidak hanya sesuai dengan atribut dan kriteria, tetapi juga menurut konsekuensinya (Saaty, 1999). Sehingga ANP sangat sesuai untuk memberikan solusi yang multiobjektif dan komprehensif dalam mencari posisi strategis dan keunggulan kompetitif dari model halal network dan crowd business syariah.

Model yang disarankan untuk pengukuran kinerja berdasarkan strategi perusahaan meliputi langkahlangkah berikut (Yüksel dan Dagdeviren, 2007): 
Langkah 1: Model construction and problem structuring

Langkah 2: Pairwise comparison matrices and priority vectors (Tabel 3)

Langkah 3: Supermatrix formation

Langkah 4: Selection of the best alternatives

Tabel 3 Nilai skala perbandingan berpasangan

\begin{tabular}{cll}
$\begin{array}{c}\text { Intensitas } \\
\text { Kepentingan }\end{array}$ & \multicolumn{1}{c}{ Definisi } & \\
\hline 1 & Sama Penting & Denjelasan \\
\hline 3 & $\begin{array}{l}\text { Tingkat Kepentingan } \\
\text { Sedang }\end{array}$ & $\begin{array}{l}\text { Pengalaman dan penilaian sedikit menguntungkan satu sama } \\
\text { lain }\end{array}$ \\
\hline 5 & Tingkat Kepentingan Kuat & Pengalaman dan penilaian sangat mendukung satu sama lain \\
\hline 7 & $\begin{array}{l}\text { Tingkat Kepentingan } \\
\text { Sangat Kuat }\end{array}$ & $\begin{array}{l}\text { Aktivitas sangat disukai dan dominasinya ditunjukkan dalam } \\
\text { praktik }\end{array}$ \\
\hline $2,4,6,8$ & Sangat Penting & $\begin{array}{l}\text { Aktivitas sangat disukai dan dominasinya ditunjukkan dalam } \\
\text { praktik }\end{array}$ \\
\hline & $\begin{array}{l}\text { Digunakan untuk mewakili kompromi antara prioritas yang } \\
\text { tercantum di atas }\end{array}$ \\
\hline
\end{tabular}

Kebalikan Jika aktivitas i memiliki salah satu bilangan bukan nol di atas yang ditetapkan padanya jika dibandingkan dengan aktivitas j, maka j memiliki nilai timbal balik jika dibandingkan dengan i.

Sumber: Yüksel dan Dagdeviren, 2007

\section{HASIL DAN PEMBAHASAN}

\section{Hasil Wawancara Terpandu}

Untuk menciptakan keunggulan kompetitif yang kuat bagi posisi strategi HNI sebagai market leader, dilakukan guided interview dan pendekatan analisis ANP. Guided interview dapat menggali informasi tentang kondisi eksisting keunggulan kompetitif HNI dari para pakar dan analisis ANP untuk meninjau kinerja kompetitif HNI dalam meningkatkan, mempertahankan dan menjadikannya sebuah keunggulan kompetitif yang berkelanjutan. Wawancara dilakukan kepada empat orang pakar dan stakeholder dari bisnis HNI. Berikut pemaran pandangan dari pihak promotor, pihak manajemen, pihak akademisi, dan pihak regulator.

\section{Sudut pandang kontributor atau key promotor}

Sebelum membahas posisi kompetitif, promotor menuturkan bahwa achievements HNI saat ini terletak pada dua sisi pandang yakni secara syariah dan secara marketing plan. Dengan strategi kompetitif, maka lahirlah keunggulan kompetitif HNI dengan diferensiasi values berupa produk yang halal berkualitas dan sistem network marketing. Keunggulan dari sisi diferensiasi values yakni HNI mempunyai pasar khas yang terbentuk dari munculnya komunitas masyarakat yang peduli dengan konsumsi halal dan produk-produk yang sesuai sunah. Pasar HNI berkembang untuk memenuhi kebutuhan tidak hanya dari produk saja, tapi juga dari kebutuhan 'misi bersama' yang dirangkum dalam ide besar HNI.

Tiga ide besar HNI sebagai strategi utama menjadikan HNI menciptakan keunggulan kompetitif. Pertama, hijrah lifestyle yang mendukung produk Muslim (halal) dan sesuai sunah. Kedua, setiap individu tidak hanya didorong sebagai pemakai produk, namun sekaligus melengkapi peran supply chain pasar halal agar kebutuhan Muslim atas produk halal bisa terjamin. Terakhir, HNI memiliki misi 
pemberdayaan ekonomi dan keluarga, yang biasanya disebut pemberdayaan potensi keluarga sebagai tagline utama HNI.

HNI juga memiliki support system yang kuat dari pihak manajemen HNI yang bersifat adil dan terbuka dalam pemberdayaan para agen. Secara syariah, seorang leader dapat mengajukan perbaikan regulasi langsung kepada perusahaan dan agen HNI lainnya juga bisa mengajukan perbaikan melalui Dewan Syariah jika dinilai terdapat sesuatu yang melanggar syariat. Terbukti pihak manajemen HNI telah melakukan perbaikan marketing plan sebanyak empat kali yang merupakan salah satu upaya berkelanjutan HNI untuk membuat perusahaan tetap syar'i, adil dan memberikan kesempatan yang sama kepada semua mitranya. Di sisi success plan, para agen dikembangkan pengetahuan dan keahliannya dalam berbisnis dan personal skills.

Bisnis HNI dimulai dengan menemukan motivasi terbesar agen sehingga mau menjalankan success plan-nya. Hal kedua yaitu kesamaan, bahwa pebisnis bisa terus bergerak dengan adanya inspirasi dari leader yang berlatar belakang sama dengannya. Tahap berikutnya yaitu edukasi, antara lain bahwa HNI merupakan bisnis rumahan, yang sifatnya murah dan sederhana namun manfaatnya maksimal dan menguntungkan. Untuk menjalankannya hampir tidak riskan karena tidak mengganggu aktivitas rutin. Hal yang keempat itu strategi berupa cara kerja benar yang disebut PCA, yaitu pakai produknya, ceritakan manfaatnya dan ajak orang lain merasakannya. Kata kunci terakhir adalah aksi atas setiap langkah yang diarahkan. Agen HNI dipastikan mempunyai mentor yang bisa mendampingi perjalanan bisnisnya.

Ada kelemahan yang otomatis menjadi tantangan pada perusahaan yaitu tentang standar pelayanan customer (dalam artian para leader) yang sebaiknya tersistem khusus. Sedangkan bisnis itu adalah tentang meraih customer bukan omzet atau pasar. Karenanya salah satu bagian utama dalam dunia bisnis konvensional adalah after sales service, dan di dunia bisnis network marketing adalah membangun loyal and fanatic market. Itulah salah satu kelemahan HNI, yaitu lemah pada sisi after sales service, bagaimana cara merawat para agen dan leader yang dibandingkan dengan network marketing lain yang lebih apresiatif dan sangat mengutamakan customer.

Kelemahan kedua adalah perekrutan anggota yang tidak disiplin, sehingga mengharuskan adanya perekrutan ulang. Perekrutan ulang biasa menjadi permasalahan dari bisnis network marketing. Sedangkan tantangan yang otomatis menjadi ancaman berkaitan dengan industri 4.0 dan teori Prof. Rhenald Kasali tentang disruption menyatakan bahwa dunia online atau dunia abad milenial adalah memanjakan orang yang malas. Tantangannya saat ini adanya pasar baru digital yang disebut marketplace, di mana produk retail maupun produk network marketing banyak dijual murah di $e$ commerce. Dari segi bisnis, seseorang merasa ada peluang bisnis lain seperti bisnis online, berjualan di marketplace atau menjadi content creator.

Dalam menyikapi hal baru di era ini, HNI membuat HNI.id sebagai e-commerce platform milik HNI yang berusaha menjawab tantangan dengan menggabungkan ketiga sisi pasar yakni retail yang memiliki produk, network marketing yang memiliki jaringan, dan e-commerce yang memiliki sistem online. Seorang produsen atau pebisnis online dapat memasukan produknya ke HNI untuk membesarkan pasar. Ada istilahnya ONOFFON (online-offline-online), yaitu HNI menggabungkan sistem online dan offline, $30 \%$ dari prospecting secara online ditindaklanjuti secara offline, sebab manusia memerlukan sentuhan dan juga pertemuan.

Secara global, HNI mempunyai peluang untuk bisa mengajak semua stakeholder Muslim di bidang ekonomi untuk bersama-sama menguasai suplai produk halal. Sebagai produsen, ditemukan banyak produksi Muslim yang dianggap bagus dan berkualitas namun sulit memasarkan produk, apalagi untuk membangun pasarnya sendiri. Sistem HNI yang mempunyai kekuatan network yang terus tumbuh dan berkembang terbukti cocok dalam pemberdayaan masyarakat atas produksi Muslim yang dianalogikan dengan plug and play. Artinya, ide besar tersebut yakni penguasaan pasar bersama seluruh stakeholder 
ekonomi Muslim baik sebagai produsen, distributor (seperti agen HNI), maupun sebagai konsumen produk (end-user) sangat besar potensinya.

Sistem network marketing berbeda dengan logika bisnis pada umumnya, karena end-user di HNI bukan hanya sebagai objek namun juga diberikan sebagian kepemilikan bisnis HNI. Hal tersebut merupakan sisi kekuatan dari network marketing HNI yang dibingkai dengan semangat spiritual mengembangkan perekonomian Islam. Sehingga, seluruh stakeholder Muslim dengan masing-masing peran ekonominya sudah memiliki kontribusi secara tidak langsung.

\section{Sudut pandang akademisi}

Key informant dari akademisi menjelaskan bahwa faktor kompetitif HNI untuk mencapai Keunggulan Kompetitif tergantung pada dasar perspektifnya. Jika dilihat dari jumlah peserta sekarang, maka dapat dikatakan HNI sebagai market leader dalam industri network marketing berbasis syariah. Dari sisi market yang spesifik, HNI itu termasuk specific market karena HNI memiliki nilai sebagai gerakan Islam yaitu orang-orang yang aware terhadap amalan sunah (hijrah). Seseorang ketika mendaftar menjadi anggota HNI bukan hanya karena bisnisnya saja, namun karena mendapatkan kajian ilmu dan sebagainya. Dari sisi kompetitif dapat dikatakan sebagai market challenger, karena memiliki kemiripan jenis produk (herba kesehatan) yang kebanyakan dipasarkan di Indonesia.

Keunggulan kompetitif HNI relatif diakui secara umum di dunia akademisi. Pertama, dari sisi pricing produk yaitu harganya tidak mahal dibandingkan produk lain sehingga bisa menyebar lebih cepat. Kedua, dari sisi pemasaran yang meraih masyarakat dengan nilai filosofi dan nilai keagamaan yang sama. Kemudian dari sisi produk, HNI memiliki banyak varian produk dibanding network marketing lain. Berikutnya, disediakan juga platform HNI.id yang tidak hanya memaparkan spesifik produk perusahaan saja, namun para agen juga bisa memasarkan produk pribadinya di HNI dan mendapatkan poin.

Kemudian terakhir dari sisi syariah tidak hanya bicara soal sistem pemasaran dan produknya saja yang ditekankan halal, tetapi dari sisi pelaku bisnis di HNI secara individu dan kelompok berkomitmen dengan ketentuan agama Islam. Contohnya dengan memberikan bonus berupa umrah dan mengingatkan untuk istiqomah bersyukur melalui bersedekah. HNI juga menerapkan strategi kolaboratif dalam proses bisnisnya, karena dalam penetapan langkah strategis di HNI selalu melibatkan pihak manajemen dan direksi. Contohnya ketika akan adanya perubahan kode etik dan mengatur perubahan mengenai sanksi atau akad-akad yang akan dievaluasi, pihak manajemen dan direksi terus dilibatkan.

Narasumber berpendapat ancaman HNI saat ini adalah perspektif masyarakat yang secara umum belum paham tentang network marketing maupun network marketing syariah. Semua network marketing dianggap sama sebagai MLM yang negatif, itulah tantangan terbesar yang harus dijawab HNI untuk memahamkan masyarakat tentang network marketing syariah. Karena sebenarnya dari sisi fatwa semua network marketing bernilai sama, hal itu merupakan strategi manajemen untuk membuat para agen menjadi lebih semangat.

Pada kasus di perusahaan network marketing syariah lain tidak menamakan jaringannya sebagai halal network, sehingga orang memasarkan produk hanya sebagai sebuah bisnis yang halal. Sedangkan HNI menggerakan orang dengan menjadikannya sebagai bagian dari dakwah dan mengajak orang lain kepada produk halal yang kemudian mendapatkan penghasilan. Jadi dari sistem teknis sebenarnya sama, namun berbeda cara pendekatan mengobarkan semangatnya. Tantangan lainnya adalah menjadikan HNI sebagai bisnis yang common bagi anak muda sekarang karena bisnis sama seperti politik yang bisa tumbuh besar jika masuk ke pasar ibu-ibu dan anak muda. HNI saat ini masih sedikit merangkul kekuatan pasar dari anak muda. Untuk menjawab hal ini, HNI perlu mencoba merangkul anak muda yang punya usaha dengan HNI.id, karena di era ini kuncinya adalah kolaborasi bisnis. 


\section{Sudut pandang manajemen $\mathrm{HNI}$}

Mulai periode 2016-2017 HNI mulai melakukan branding sebagai Halal Network International sebagai ikhtiar membesarkan pasar halal secara global dan juga didukung dengan permintaan pembukaan cabang awal di Malaysia dan Thailand. HNI diposisikan sebagai hub atau penghubung dari berbagai keperluan dan kebutuhan. Ada vendor penyedia produk dan agen sebagai potensi pemilik jaringan distribusi. Kebutuhan pasar di HNI terus dievaluasi sehingga edukasi langsung kepada promotor atau agen menjadi sangat penting agar dapat beradaptasi dengan pasar. Saat pandemi, HNI membuat production house konten sendiri dalam rangka beradaptasi dan agar bisa semakin go international. Agen juga diberikan promosi dan keuntungan tertentu secara berkala untuk meningkatkan motivasi dalam mensyiarkan produk halal.

Kekuatan HNI didefinisikan dalam 5 PILAR PASTI yang membangun dan mengokohkan HNI. Secara segmentasi pasar, bisa dikatakan HNI berada di industri blue ocean yang nilai kompetisinya minimal. HNI mencoba untuk selalu berkembang agar bisa menjadi penyedia produk halal dan thoyyib terbaik di hati masyarakat yang dibuktikan dengan kenaikan omzet setiap tahunnya. Kelima PILAR PASTI diibaratkan sebagai tiang-tiang utama yang membangun HNI untuk dijadikan pertimbangan dalam membangun ekonomi umat dengan memberdayakan potensi keluarga. Pilar ini menjadikan HNI kuat dan layak dijadikan sebagai mitra dalam bidang kesehatan dan ekonomi keluarga.

\section{Sudut pandang regulator}

Komara (2017) menyatakan bahwa follow up merupakan resep sukses untuk para pegiat network marketing. Dikatakan bahwa banyak networker yang tidak menyadari sarana komunikasi itu sangat penting dalam membangun jaringan, khususnya dalam mem-follow up prospek. Sebuah studi yang dilakukan Carnegie Foundation tentang kenapa konsumen berhenti membeli produk menyatakan bahwa hanya $12 \%$ konsumen beralasan tidak puas dengan produk maupun perusahaan, sedangkan 55\% lantaran putus hubungan dengan perusahaan.

Terdapat aturan kesuksesan perdagangan yang tidak tertulis, yaitu ketika konsumen tidak berhenti membeli produk dan menjadi konsumen yang loyal. Konsumen loyal yang telah merasakan khasiat dan manfaat produk, kemungkinan besar akan merekomendasikan produk tersebut kepada konsumen lainnya. Namun kelemahan para networker tersebut adalah tidak melakukan follow up kepada konsumen, khususnya saat mereka melakukan pembelian kedua produk tersebut dan berharap konsumen akan secara otomatis menghubungi dirinya. Ketiadaan follow up menghasilkan efek buruk pada hasil besar yang bisa diraih dalam penjualan.

Komara (2016) menegaskan bahwa maraknya kasus money game, bukan hanya menimbulkan keprihatinan berbagai pihak, namun juga membuat citra industri network marketing menjadi negatif di masyarakat. Akibatnya, para networker sulit bergerak dalam bisnis ini. Sementara ada beberapa ciri network marketing yang benar dan murni, yaitu network marketing memberikan bonus berdasarkan pembelian produk yang kemudian menjadi omzet grup, bukan berdasarkan pertumbuhan jaringan. Bonus akan terus mengalir sepanjang ada omzet pembelian grup jaringan, bahkan bonus tersebut dapat dinikmati oleh ahli waris jika member tersebut meninggal dunia.

Network marketing yang baik tidak hanya soal menjual produk, namun juga memiliki rancangan pendidikan yang memberikan perubahan hidup. Pendidikan sangat penting melebihi nilai dari produk itu sendiri. Karena itu baik secara lembaga maupun individu, seorang network marketer perlu memastikan rancangan pendidikannya, seperti sikap terhadap kesuksesan, keahlian memimpin dan komunikasi, keahlian mengatasi ketakutan pribadi dan mengatasi penolakan, keahlian manajemen uang dan waktu, penentuan tujuan, dan sebagainya. Kesuksesan network marketing yang benar dan murni begitu dinamis dan cair serta tidak ditentukan oleh atribut sosial seperti modal, gelar pendidikan, kemampuan, keturunan keluarga ataupun keawalan registrasi. Kesuksesan diraih melalui kemauan yang kuat dan mau berkorban menjalankan karirnya. 


\section{Strategi Penentu Crowd Business syariah}

Pada pasar Muslim, ditemukan bahwa crowd-based enterprise mampu bersaing secara berkelanjutan dengan inovasi basis model bisnis bersama peluang monetisasinya dan unsur suksesnya. Dikembangakan berdasarkan syariah Islam, Hoque et al. (2018) menjabarkan bahwa social enterprise dapat menggunakan equity-based model dalam crowdsourcing bisnis, sehingga dapat mempertahankan keunggulan kompetitifnya secara berkelanjutan yang didukung dengan akomodasi kebijakan regulator.

Kemudian, Dawson dan Bynghail (2012) menulis bahwa model crowd business pasar produk seperti HNI, bisa melakukan monetisasi hanya pada product dan content sales dari sebelas macam peluang monetisasi lainnya. Karena sejak awal berdiri, HNI bekerjasama untuk menjadikan produk mitra yang halal dan berkualitas untuk bisa dipasarkan oleh perusahaan sebagai salah satu cara mencapai tujuan perusahaan dalam pemberdayaan. Dari sisi success factors, keduanya juga memaparkan sebelas unsur esensi dalam implementasi crowd business berdasarkan tiga karakter. Sembilan unsur yang dianggap signifikan terhadap pasar produk HNI, kemudian dikompres menjadi tiga unsur yang menentukan kesuksesan crowd business model.

Dari studi literatur tersebut dan dengan hasil jajak pendapat narasumber ahli dari empat sudut pandang terhadap strategi crowd business syariah, terdapat lima kategori modal institusional dalam praktik bisnis HNI untuk mengoptimalkan sustainable strategic performance. Modal institusional tersebut antara lain crowd business model base, product and content sales, technology and buyer fulfilment, kualitas dan keluasan kontributor dan reputation and quality control.

Sehingga dalam penelitian ini, ada lima strategi penentu crowd business syariah yang akan digunakan:

1. Crowd Business Equity Base berupa pemberdayaan ekonomi Muslim dan investasi bisnis bersama.

2. Product and Content Sales berupa produk yang berkualitas, halal, sesuai sunah dengan metode pemasaran yang syar'i.

3. Technology and Buyer Fulfilment berupa digitalisasi kantor virtual crowd member, sistem informasi penjualan untuk para agen crowd dan marketplace untuk Muslim crowd pada umumnya dan khususnya crowd member, loyalitas pelanggan yang fanatik terhadap produk halal dan thoyyib dan harga produk yang terjangkau.

4. Kualitas dan Kuantitas Kontributor berupa kontributor yang berkompeten, bersinergi dan meluas.

5. Reputation and Quality Control berupa individu manajemen yang berintegritas dalam mengawal kualitas produk yang halal dan premium, serta mensupervisi rantai pasok dan distribusi produk oleh para kontributor Muslim.

\section{Strategi Penentu Keunggulan Kompetitif}

Berdasarkan studi literatur dan didukung oleh data sekunder dan keterangan para narasumber dapat diketahui bahwa terdapat lima kategori yang menentukan keunggulan kompetitif suatu perusahaan berbasis network marketing. Pertama, menurut Keong dan Dastane (2019) bahwa unsur yang paling mempengaruhi keunggulan kompetitif yang berkelanjutan adalah company image. Unsur berikutnya yakni leadership yang diikuti unsur distributor reward system dan distributor training system. Ditemukan bahwa distributor sangat mengandalkan sistem yang stabil dan masa depan perusahaan yang lebih cerah. Hal ini dapat diketahui melalui strategi kinerja dan kepemimpinan visioner dalam manajemen perusahaan yang sukses berkelanjutan.

Selain itu, studi ini juga mengungkapkan bahwa perusahaan network marketing dunia mampu meningkatkan keunggulan kompetitifnya dengan unsur product innovation yang jadi unsur terakhir dalam penelitian ini. Distribution system dan promotor training system juga disebutkan para narasumber sebagai elemen berpengaruh atas keunggulan kompetitif perusahaan sebagai unsur ketiga dan keempat. Berdasarkan karakternya, kelima unsur tersebut termasuk ke dalam modal sumber daya (resource capital) bagi perusahaan dalam mencapai keunggulan kompetitif. Sehingga dalam penelitian ini ada lima strategi penentu competitive advantage yang akan digunakan: 
1. Company Image berupa branding dengan strategi yang matang.

2. Leadership berupa kepemimpinan yang proaktif baik dari manajerial entitas usaha maupun dari kontributor.

3. Distributor Reward System berupa kompensasi atau rekognisi atas perannya turut menyediakan, mendistribusikan atau mensosialisasikan lebih luas sesuai jalur dan perangkat yang disediakan oleh entitas usaha.

4. Distributor Training System berupa perangkat sistem yang telah disediakan oleh entitas usaha agar para kontributor dapat berkontribusi lebih baik.

5. Product Innovation berupa diferensiasi produk yang unik dan terus dikembangkan oleh entitas usaha agar para kontributor semakin bertumbuh dan loyal.

\section{Strategi Penentu Sustainable Competitive Advantage}

Menurut Oliver (1997) ada dua kategori sustainable competitive advantage yaitu modal institusional dan juga resource capital yang diperkuat Hafeez et al. (2002). Selain itu, Mukerjee (2016), Keong dan Dastane (2019) menilai adanya alternatif dalam mencapai sustainable competitive advantage yaitu efektivitas manajemen. Sementara menurut David dan David (2016) dan Morioka et al. (2017) efisiensi manajemen juga dinilai penting untuk keberlangsungan keunggulan kompetitif. Dari pemaparan tersebut, terdapat sepuluh strategi yang dikelompokkan kedalam dua kategori yaitu resource capital dan institutional capital dalam menentukan strategi keunggulan kompetitif yang berkelanjutan bagi crowd business syariah.

Tabel 4 Strategi HNI dalam sustainable strategic performance

\begin{tabular}{|c|c|c|}
\hline Kategori & Strategi & Praktik Network Marketing HNI \\
\hline \multirow[t]{5}{*}{ Resource Capital (RC) } & Company Image (R1) & Halal Network International \\
\hline & Leadership (R2) & Promotor's Leadership \\
\hline & Distribution System (R3) & Distribution Channel \& Perangkatnya \\
\hline & Promotor Training System (R4) & Success Plan, Support System, dan perangkat \\
\hline & Product Innovation (R5) & Product Differentiation \\
\hline \multirow[t]{5}{*}{ Institutional Capital (IC) } & Crowdbusiness Model Base (I1) & $\begin{array}{l}\text { Empowerment Muslim Crowd } \\
\text { Equity-based Crowdbusiness }\end{array}$ \\
\hline & Product and Content Sales (I2) & $\begin{array}{l}\text { Halal Product } \\
\text { Thibbun Nabawi (Herbal sunah) } \\
\text { Network Marketing }\end{array}$ \\
\hline & $\begin{array}{l}\text { Technology and Buyer Fulfilment } \\
\text { (I3) }\end{array}$ & $\begin{array}{l}\text { Teknologi (AVO, HSIS \& HNI.id) } \\
\text { Hijrah Interested Customers } \\
\text { Harga Produk Terjangkau }\end{array}$ \\
\hline & $\begin{array}{l}\text { Kualitas dan Kuantitas Promotor } \\
\text { (I4) }\end{array}$ & $\begin{array}{l}\text { Trained Promotors } \\
\text { Agenstocks chain (BC-AC-DC-SC) }\end{array}$ \\
\hline & Reputation and Quality Control (I5) & $\begin{array}{l}\text { Management Integrity } \\
\text { Empowerment Muslim- Halal Supply Chain } \\
\text { Produk berkualitas premium }\end{array}$ \\
\hline
\end{tabular}

Sumber: Penulis (2020) 
Pada Tabel 4, kategori modal sumber daya terdiri atas lima strategi penentu sustainable strategic performance. Pertama, citra perusahaan sebagai halal network atau MLM syariah yang diakui halal baik secara produk maupun sistem bisnisnya. Kedua yaitu kepemimpinan oleh promotor dalam mengkampanyekan nilai halal. Ketiga yaitu sistem saluran distribusi perusahaan dan perangkatnya. Keempat yaitu sistem pelatihan promotor berupa success plan, support system dan perangkatnya yang mengembangkan promotor menjadi modal sumber daya. Kelima yaitu inovasi produk berupa diferensiasi produk yang halal dan thoyyib, dengan kualitas premium serta peluang bisnisnya.

Pada kategori kedua, unsur modal institusional dalam penelitian ini juga terbagi ke dalam lima strategi penentu kinerja kompetitif yang berkelanjutan. Konteks bisnis HNI di sini menjadi berbeda karena modal institusional juga menentukan pemanfaatan modal sumber daya yang optimal. Yang pertama, basis model crowd business HNI berdasarkan ekuitas yang memberdayakan Muslim crowd. Kedua adalah penjualan produk dan konten atas produk halal yang sesuai sunah dengan sistem sharia network marketing. Selanjutnya, teknologi dan pemenuhan pembeli meliputi teknologi sistem informasi sebagai distributor, harga produk yang terjangkau dan tingkat penunaian kebutuhan segmen peminat hijrah lifestyle. Kemudian, kualitas dan kuantitas promotor berupa banyaknya promotor terlatih dan sebagai rantai distribusi produk kepada konsumen. Terakhir, reputasi dan kontrol kualitas termasuk integritas manajemen, pemberdayaan Muslim dalam rantai suplai halal dan jaminan atas kualitas produk yang terbaik.

\section{Model Construction and Problem Structuring}

Inovasi dan strategi kompetitif terhadap perkembangan era yang dilakukan HNI secara tidak langsung menciptakan keunggulan kompetitif dengan industri halal lainnya. Identifikasi keunggulan kompetitif ini dapat memudahkan pelaku bisnis untuk meningkatkan dan mempertahankan keunggulan kompetitifnya yang berkelanjutan. Hasil studi literatur dan sudut pandang dari berbagai sisi key informant melalui guided interview merupakan komponen untuk mengkaji kunci strategi HNI dalam dalam menghadapi peluang dan tantangan bisnis.

Guided interview dilakukan dengan presiden CELL (asosiasi key promotor) di HNI selaku promotor, manajemen, pakar akademisi, dan regulator atas sistem network marketing yang digunakan HNI. Pembahasan dan saran dari para pakar dipertimbangkan dalam penyusunan unsur kompetitif HNI. Guided interview kepada para pakar dilakukan secara terpisah, sehingga pembahasan dan saran dari pakar perlu dilakukan validasi. Hasil wawancara tersebut menghasilkan perubahan dan penambahan dari unsur kompetitif.

Model sustainable strategic performance dari crowd business syariah dibentuk oleh kategori dan kategori yang ditentukan pada langkah pertama ditunjukkan pada Tabel 4. Bagian pertama mencakup tujuan model, ditentukan sebagai 'Unsur Kompetitif Crowd Business Syariah'. Langkah kedua mencakup kategori yang akan digunakan dalam pengukuran kinerja yang terhubung ke tujuan dengan satu panah arah yakni 'Unsur Strategi Berkelanjutan Crowd Business Syariah'. Selanjutnya, panah pada tahap ketiga mewakili saling ketergantungan di antara kategori tersebut. Dalam tahap ini, saling ketergantungan antara kategori diperhitungkan untuk menganalisis pengaruh antarkategori tersebut. Dengan asumsi bahwa tidak ada ketergantungan di antara elemen dalam kategori yang sama, perbandingan berpasangan unsur menggunakan skala 1-9 dibuat berhubungan dengan tujuan penelitian.

Pada Gambar 4, untuk menentukan sustainable strategic performance, model ANP mencakup atas empat belas variabel baik berupa kategori, elemen kategori maupun strategi alternatif. Sebagaimana studi literatur, strategi alternatif yang akan menjadi acuan dalam penentuan strategi kinerja berkelanjutan terbagi dua yakni strategi efektif dan strategi efisien. Dari model ini dapat diketahui bahwa kedua kategori modal sumberdaya dan institusional dari crowd business syariah dan kesepuluh elemen dari kedua kategori, secara simultan memiliki keterkaitan dalam menentukan alternatif strategi antarstrategi efektif atau strategi efisien. 


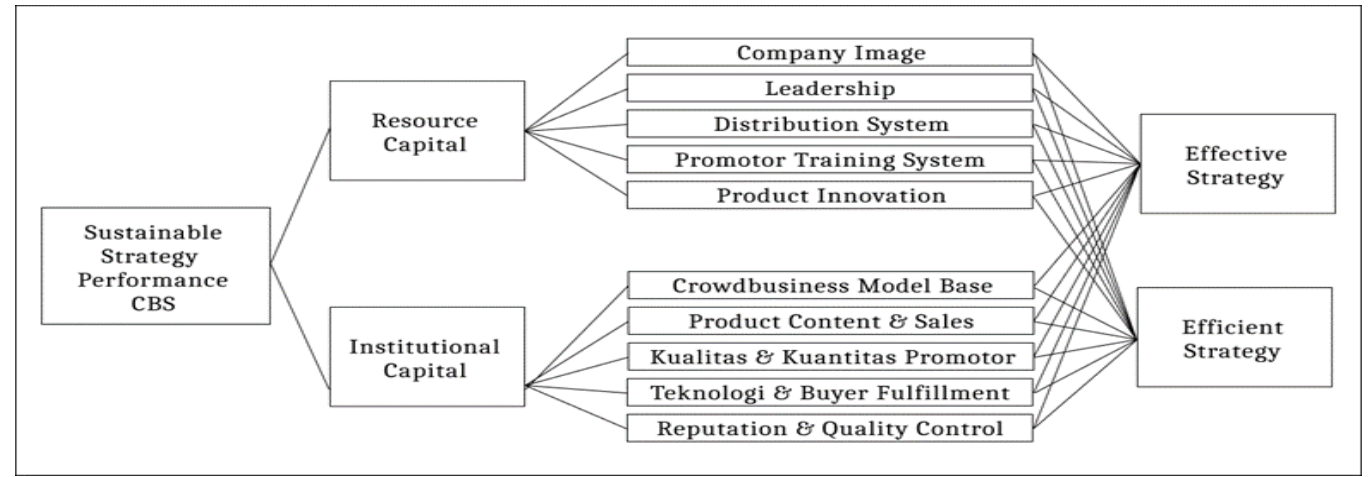

Sumber: Data primer, 2020 (diolah)

Gambar 4 Model ANP untuk menentukan sustainable strategic performance

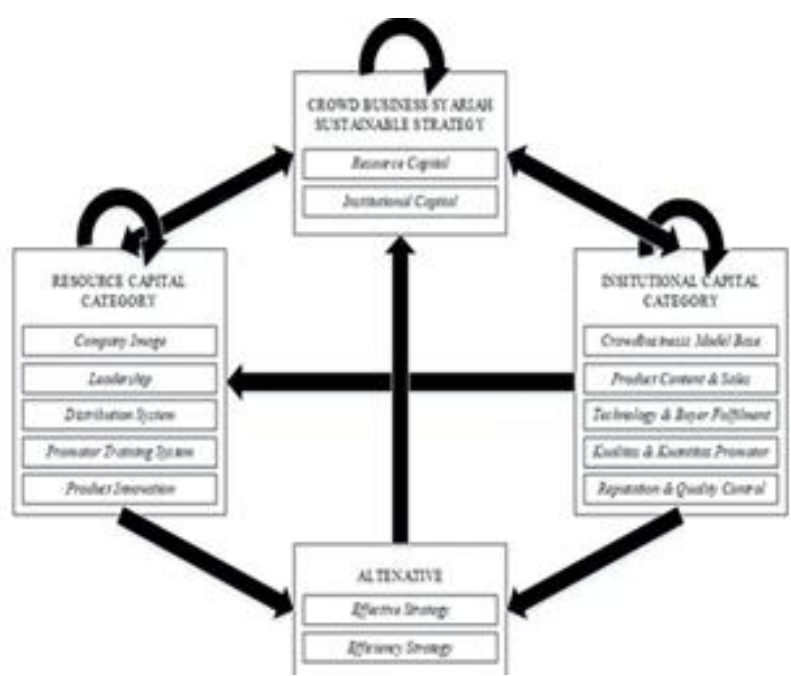

Sumber: Data primer, 2020 (diolah)

Gambar 5 Model proses jaringan antarunsur

\section{Pairwise Comparison Matrices and Priority Vectors}

Semua perbandingan berpasangan dalam aplikasi dilakukan oleh para ahli di bidangnya. Matriks perbandingan berpasangan, dianalisis menggunakan Super Decision v3.2 software dan diperoleh nilai vektor eigen serta rasio konsistensi (CR). Berikut pemodelan dan pembobotan crowd business syariah.

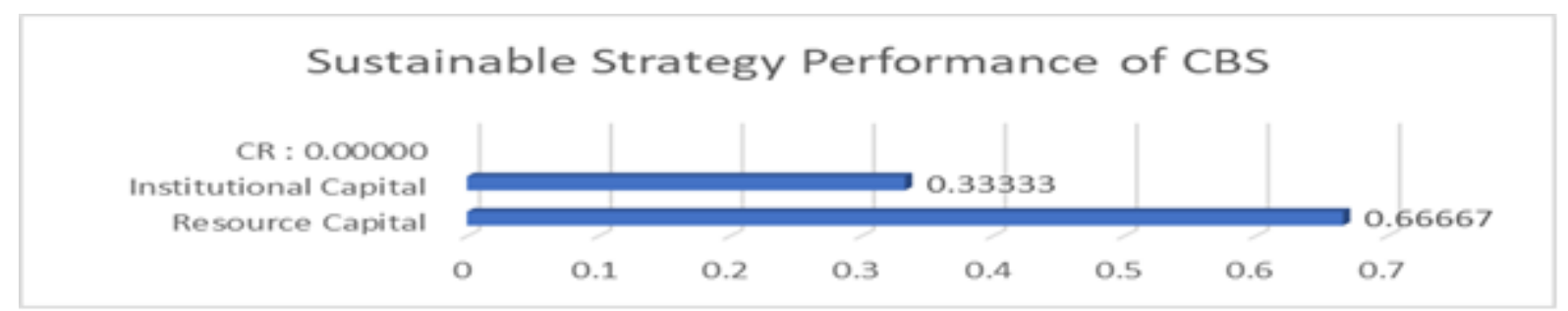

Sumber: Data primer, 2020 (diolah)

Gambar 6 Kinerja perbandingan unsur strategi

Berdasarkan Gambar 6, kinerja unsur strategi resource capital (0.66667) terhadap strategi crowd business syariah berkelanjutan secara keseluruhan lebih utama dibanding institutional capital (0.33333). Pengaruh antarunsur sebesar 0.00000 berarti tidak terdapat outer dependence sub-unsur pada kedua unsur strategi tersebut. Nilai matriks unsur terhadap unsur strategi itu sendiri semuanya bernilai nol menunjukkan bahwa tidak terdapat inner dependence antarunsur strategi di dalamnya. 
Selain itu, pada Gambar 7, dapat diketahui bahwa dalam menentukan kinerja strategi resource capital antarklaster ternyata unsur R1 (company image) menjadi prioritas utama dengan nilai 0.31681 yang disusul oleh unsur R2 (leadership) dengan nilai 0.28792. Unsur R1 dianggap 2 kali lebih penting daripada unsur R2, R3 (distribution system), R4 (training system), dan unsur R5 (product innovation). Dari nilai consistency ratio $(\mathrm{CR})$ dapat dipahami konsistensi responden dalam penilaian perbandingan berpasangan ini yang dianggap konsisten jika $\mathrm{CR}<0.1$. Nilai $\mathrm{CR}$ dalam perbandingan ini adalah sebesar 0.06987, sehingga dapat disimpulkan bahwa responden konsisten dalam menilai perbandingan berpasangan tersebut.

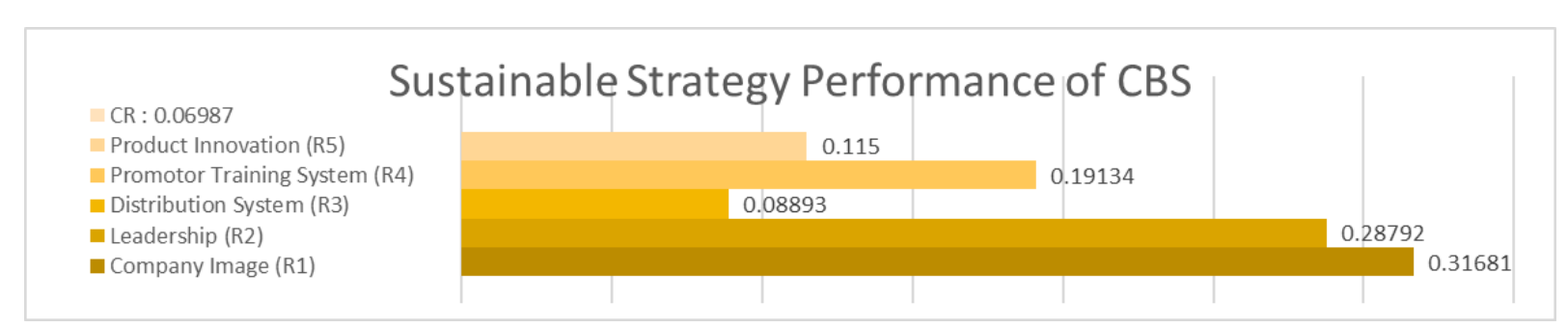

Sumber: Data primer, 2020 (diolah)

Gambar 7 Urutan prioritas antarunsur strategi resource capital

Selanjutnya pada Gambar 8 diketahui bahwa dalam menentukan kinerja strategi instiutional capital antarklaster ternyata strategi I4 (kualitas dan kuantitas promotor) menjadi prioritas utama dengan nilai 0.31483 yang disusul oleh unsur I1 (crowd business model base) dengan nilai 0.29322. Unsur I4 dianggap sama penting dengan unsur I1, 2 kali lebih penting daripada unsur I2 (product content sales) dan unsur I3 (technology and buyer fulfilment) dan 5 kali lebih penting daripada unsur I5 (reputation and quality control). Nilai consistency ratio (CR) dalam perbandingan ini adalah sebesar 0.02417, sehingga berarti masih di bawah nilai 0.10000 dan dapat disimpulkan responden konsisten dalam menilai perbandingan berpasangan tersebut.

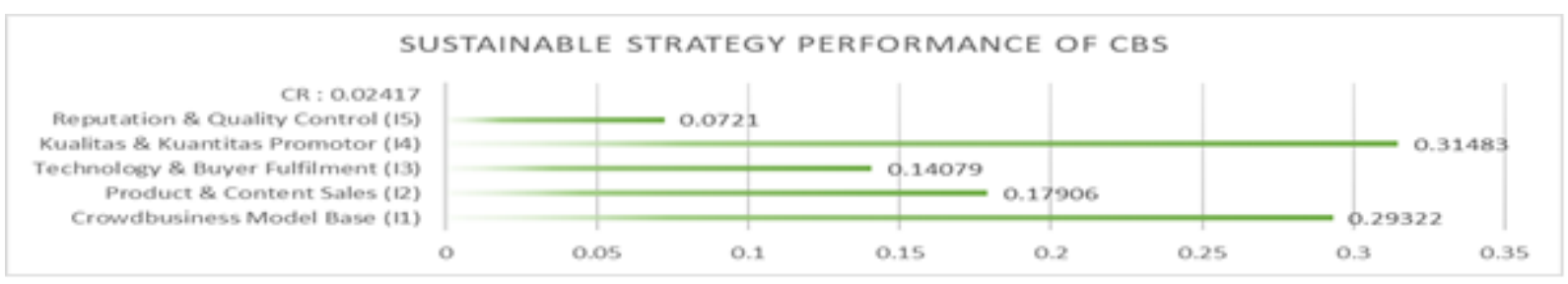

Sumber: Data primer, 2020 (diolah)

Gambar 8 Urutan prioritas antarunsur strategi institutional capital

\section{Supermatrix Formation}

Supermatriks limit ini berisi prioritas lokal yang diturunkan dari pairwise comparison di seluruh jaringan seperti yang ditunjukkan pada Gambar 9. Misalnya, prioritas resource and institutional capital, sehubungan dengan effective strategy ditunjukkan pada sepuluh baris di bawah. Ada dua faktor yang paling berpengaruh yakni company image (0.15939) dan leadership (0.06970). Nilai-nilai pada limiting supermatrix adalah prioritas untuk semua node yang dapat dibaca dari kolom mana saja. Dapat diketahui pula bahwa karakteristik resource capital (0.25695) pada effective strategy adalah agak lebih kuat atau hampir tiga kali lebih disukai daripada aspek institutional capital (0.09868).

Di antara kesepuluh strategi, company image dianggap 2.3 kali lebih penting dari leadership dan 3.7 kali lebih penting dari promotor training system dalam formulasi strategi keunggulan kompetitif berkelanjutan bagi perusahaan crowd business syariah ini. Berikutnya, company image dianggap 5.5 kali lebih penting daripada product innovation dan 6.7 kali lebih penting daripada distribution system antarstrategi resource capital. Dibanding dengan klaster institutional capital, company image dianggap 
15.4 kali lebih penting dari kualitas \& kuantitas promotor dan 16.5 kali lebih penting dari crowd business model base.

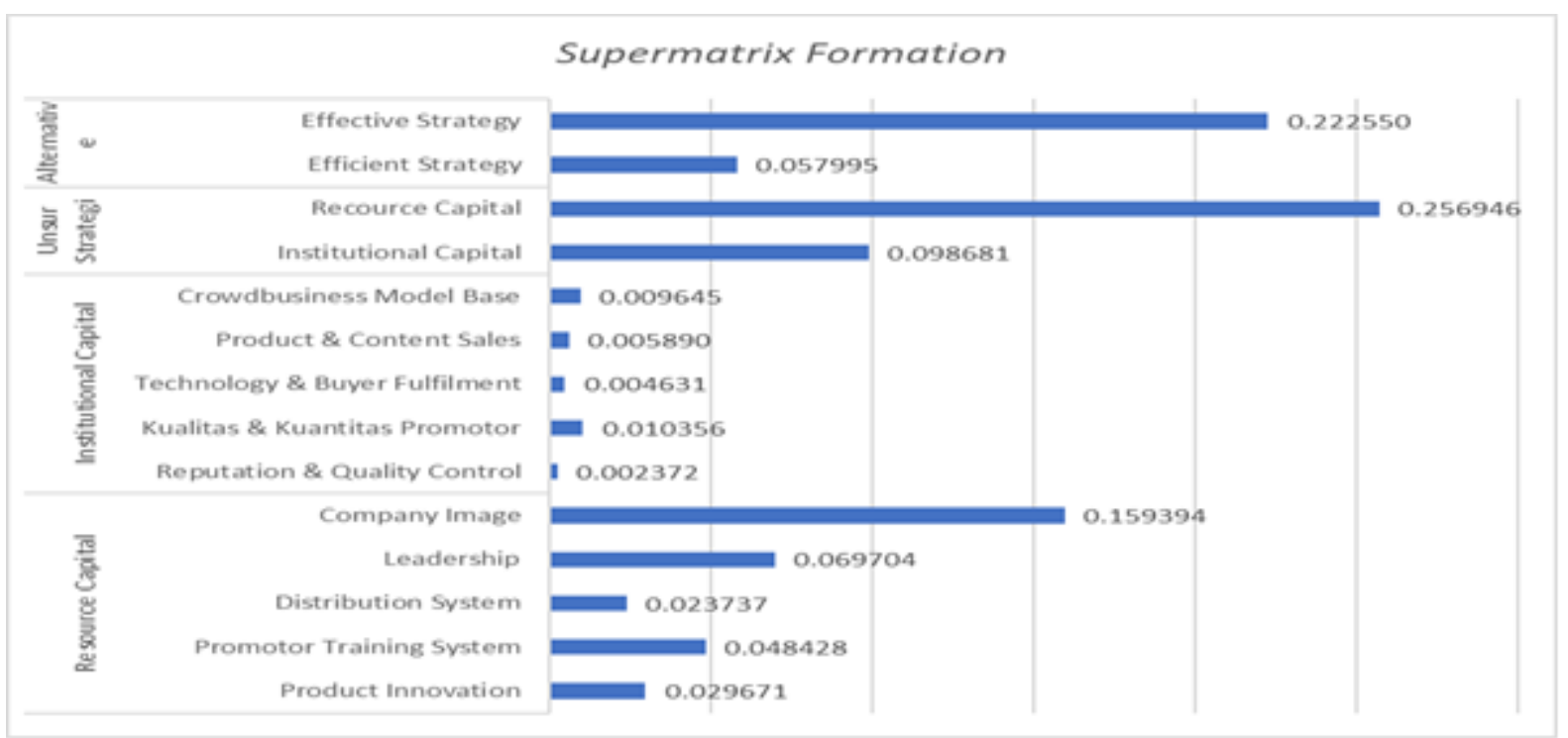

Sumber: Data primer, 2020 (diolah)

Gambar 9 Formasi supermatriks untuk sustainable strategic performance

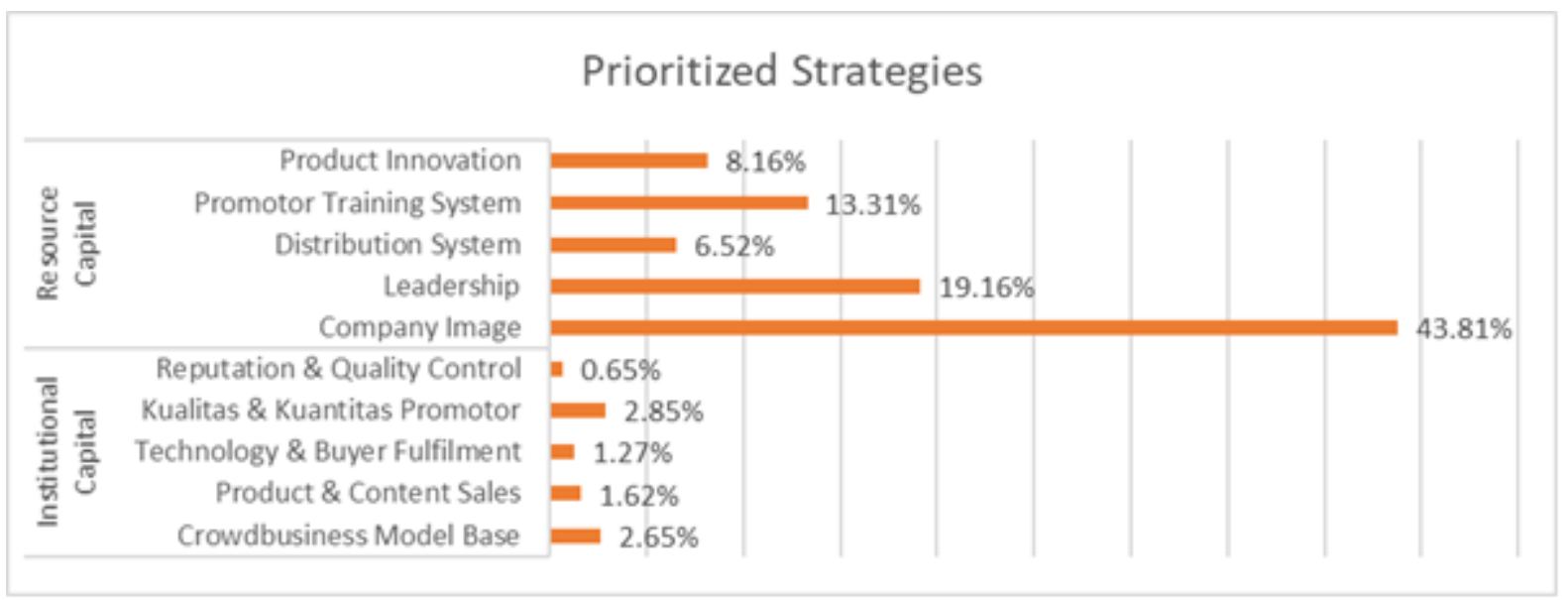

Sumber: Data primer, 2020 (diolah)

Gambar 10 Priotitas strategi untuk sustainable strategic performance

Berdasarkan hasil pengolahan data perbandingan berpasangan dari responden ahli dengan software Super Decisions v3.2 dapat diketahui rekapitulasi rata-rata bobot normalisasi terhadap 10 strategi tanpa memasukkan alternatif maupun unsur modal crowd business syariah. Rata-rata bobot ternormalisasi dapat dilihat pada Gambar 10. Di antara sepuluh strategi, company image memiliki pengaruh sebesar 43.8\% yang berarti harus menjadi concern utama dalam strategi keunggulan kompetitif berkelanjutan suatu crowd business syariah. Concern kedua ditunjukkan oleh nilai leadership sebesar $19.2 \%$ dan promotor training system senilai $13.3 \%$. Berikutnya, product innovation dan distribution system yang mempunyai pengaruh masing-masing senilai $8.2 \%$ dan $6.5 \%$ berada pada concern ketiga. Terakhir, subunsur kualitas \& kuantitas promotor (2.8\%) dan crowd business model base (2.7\%) menjadi concern tersier dalam penentuan strategi perusahaan crowd business syariah yang berkelanjutan. 


\section{Selection of the Best Alternatives}

Perhitungan priorities menampilkan prioritas dalam dua cara, yakni tampilan formasi supermatriks dan dengan normalisasi prioritas berdasarkan klaster (Gambar 11). Dari sini dapat diketahui bahwa terdapat tujuh strategi yang perlu menjadi prioritas dalam strategi kinerja perusahaan. Pada institutional capital, kualitas dan kuantitas promotor dan crowd business model base memiliki pengaruh paling tinggi bagi strategi kompetitif berkelanjutan. Elemen tersebut masing-masing mewakili kinerja institutional capital sebesar 0.315 dan 0.293 atas crowd business syariah. Di sisi resource capital, terlihat bahwa company image paling berpengaruh terhadap keunggulan kompetitif perusahaan dengan nilai 0.482 . Kemudian proporsi pengaruh berikutnya yakni sub-unsur leadership (0.211) dan promotor training system $(0.146)$ yang diiringi oleh product innovation (0.090) dan distribution system (0.072).

Semua sub-unsur resource capital perlu menjadi prioritas dalam penentuan strategi keunggulan kompetitif berkelanjutan. Sebaliknya, ditemukan tiga strategi yang bukan merupakan prioritas terhadap keunggulan berkelanjutan modal crowd business syariah. Tiga variabel tersebut secara berurutan yakni reputation and quality control, technology and buyer fulfilment dan unsur product and content sales yang dapat diketahui dari nilai limiting supermatrix. Di antara kesepuluh strategi, ketiga variabel ini yang paling lemah dalam memengaruhi keunggulan berkelanjutan bagi perusahaan.

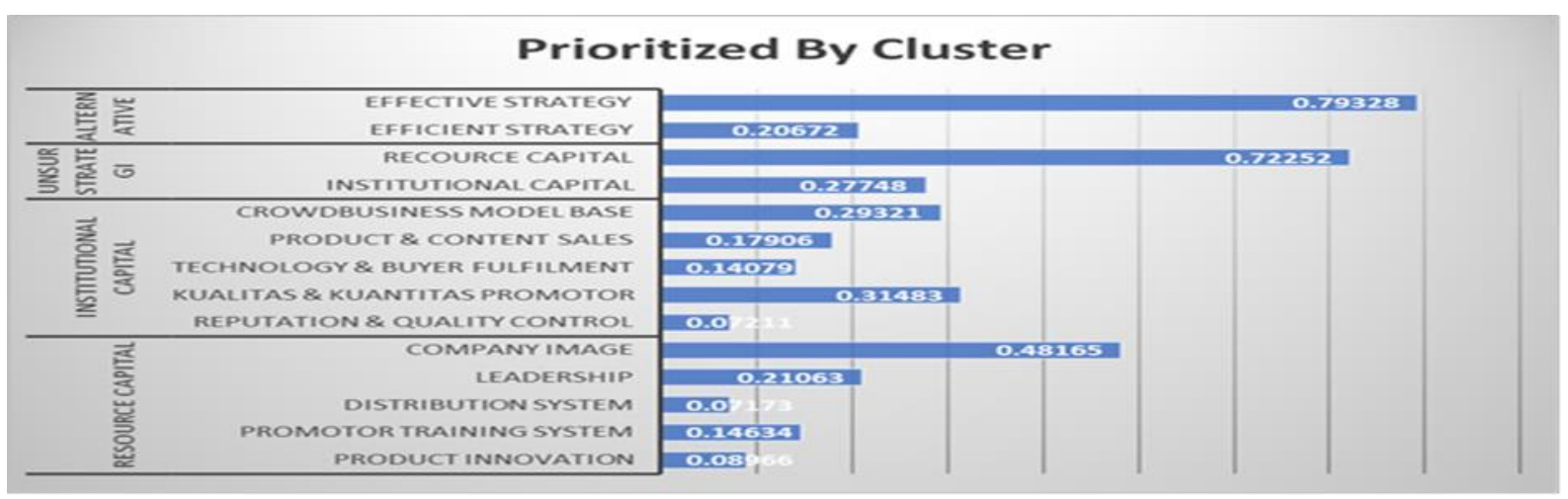

Sumber: Dara primer, 2020 (diolah)

Gambar 11 Prioritas supermatriks limit terhadap sustainable strategic performance

Computations synthesize menampilkan hasil akhir dalam tiga cara seperti yang ditunjukkan pada Gambar 11. Sementara prioritas supermatriks limit diberikan kolom raw, ditunjukkan pula hasil yang dinormalisasi untuk setiap klaster. Kolom ideal menunjukkan hasil yang diperoleh dengan membagi nilai di kolom normalisasi atau limiting dengan nilai terbesar di kolom.

Alternatif terbaik adalah effective strategy dengan nilai ANP sebesar 0.79328. Effective strategy diperoleh dari keunggulan dalam memanfaatkan sumberdaya yang optimal dan juga mampu dengan baik mengelola modal institutional. Efficient strategy agak berlebihan atas pemanfaatan sumber daya, dan belum begitu baik dalam pengelolaan modal institutional. Sehingga alternatif ini bukan terbaik secara keseluruhan.

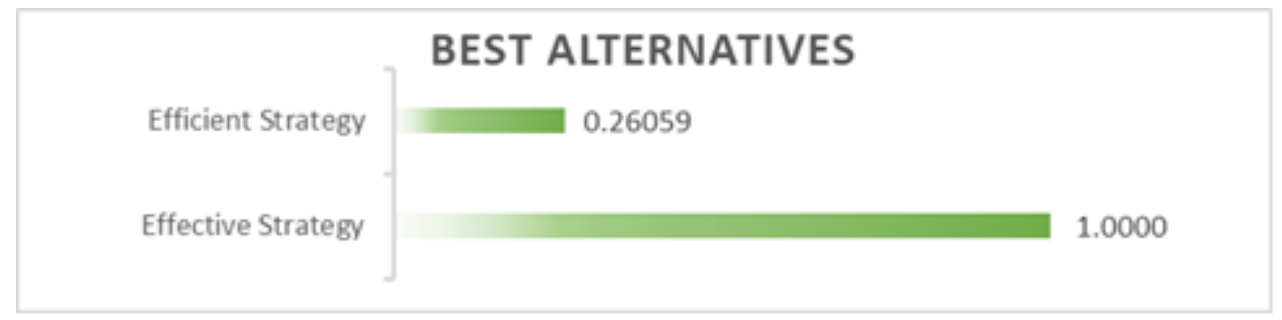

Sumber: Data primer, 2020 (Diolah)

Gambar 12 Hasil atas penentuan alternatif untuk sustainable strategic performance 


\section{Implikasi Manajerial}

1. Berdasarkan prioritas dari penilaian responden ahli, strategi kinerja perlu direncanakan, diimplementasikan dan dievaluasi secara berkala dengan saksama untuk mencapai tujuan strategi crowd business syariah yang berkelanjutan. Kemudian, prioritas strategi tersebut diketahui perbandingan bobot atau tingkat kepentingannya dalam kinerja perusahaan crowd business syariah untuk mencapai sustainable competitive advantage. Di bawah ini pemaparannya:

a. Effective strategy harus menjadi benchmark crowd business syariah dalam memilih alternatif strategi yang ada untuk mencapai tujuannya. Selanjutnya, HNI perlu memproritaskan effective strategy sebesar $79.33 \%$ atau mendekati empat kali dibanding efficient strategy.

b. Strategi terbaik harus terus dikembangkan crowd business syariah hingga memaksimalkan resource capital sebagai suatu kesatuan nilai agar dapat melahirkan sebuah core competence yang unik dan memiliki daya saing. Dari kategori pengadaan dan perlindungan atas modal sumber daya yang dimiliki ini, HNI harus memprioritaskan resource capital sebesar $72.25 \%$ atau 2.6 kali dibanding institutional capital, sehingga HNI dianggap sukses jika mampu mengelola sumber daya yang tidak dapat ditiru.

c. Company image dalam bentuk branding merupakan strategi yang dianggap paling kuat ketiga untuk meningkatkan performa sustainable strategy bagi crowd business syariah. Dari segi penentu di antara 5 strategi dalam kategori modal sumber daya, company image dinilai paling kuat dengan nilai $48.16 \%$ sehingga HNI perlu terus meningkatan citranya sebagai halal network karena dianggap mampu menciptakan sumber daya unik dibanding strategi lainnya.

2. Berdasarkan hasil studi literatur, data sekunder dan keterangan para ahli, 5 strategi dari modal sumber daya pada perusahaan berbasis crowd business syariah juga ditemukan menjadi prioritas terpenting berikutnya yang menentukan sustainable strategic performance. Berikut ini dijabarkan bentuk-bentuk strategi dalam manajemennya:

a. Company image berupa branding dengan strategi yang matang.

b. Leadership berupa kepemimpinan yang proaktif baik dari manajerial entitas usaha maupun dari kontributor.

c. Distribution system berupa kompensasi atau rekognisi atas perannya turut menyediakan, mendistribusikan atau mensosialisasikan lebih luas sesuai jalur dan perangkat yang disediakan oleh entitas usaha.

d. Promotor training system berupa perangkat sistem yang telah disediakan oleh entitas usaha agar para kontributor dapat berkontribusi lebih dalam.

e. Produk innovation berupa diferensiasi produk yang unik dan terus dikembangkan oleh entitas usaha agar para kontributor semakin bertumbuh dan loyal.

3. Selanjutnya, berdasarkan hasil jajak pendapat dari 4 narasumber, studi literatur dan analisis data responden, berikut ditemukan 2 dari 5 modal institusional yang perlu menjadi strategi dalam perusahaan crowd business syariah untuk menentukan sustainable strategic performance yaitu:

a. Crowd business equity base yakni berupa pemberdayaan ekonomi Muslim dan investasi bisnis bersama. Dari segi penentu di antara 5 sub-unsur klaster institutional capital, crowd business equity base crowd business syariah dinilai terkuat kedua dengan nilai $29.32 \%$ karena basis model ini dianggap dapat mempertahankan kinerja unggul perusahaan dengan memaksimalkan potensi kontribusi dan investasi di pasar Muslim.

b. Kualitas dan kuantitas kontributor yaitu berupa kontributor yang berkompeten dan bersinergi. Dari segi penentu di antara 5 sub-unsur klaster institutional capital, kualitas dan kuantitas promotor crowd business syariah dinilai paling kuat dengan nilai $31.48 \%$ karena dianggap dapat mengoptimalkan kinerja dengan budaya continuous improvement dan knowledge sharing. 
c. Ketiga strategi lainnya perlu mendapat perhatian khusus dan diharapkan sudah mapan sebagai manajemen efektif dalam model crowd business syariah untuk mencapai tujuan sustainable competitive advantage.

i. $\quad$ Product and content sales perlu menjadi pilar strategi dalam bentuk konten marketing \& sales di antaranya promosi halal product dan herbal sunah serta metode network marketing.

ii. Technology perlu menjadi pilar strategi dalam bentuk digitalisasi informasi yang diperlukan. Buyer fulfilment perlu menjadi pilar strategi dalam bentuk pemenuhan pembeli pada pilar produk dalam konteks kemudahan mendapat produk, keterjangkauan harga dan hijrah interested customers atau pelanggan yang loyal.

iii. Reputation perlu menjadi pilar strategi dalam bentuk integritas manajemen dan quality control perlu menjadi pilar strategi dalam bentuk pengembangan produk dan proses bisnis.

\section{SIMPULAN}

\section{Simpulan}

Hasil penelitian ini mengkaji tentang strategi sustainable competitive advantage dengan mengkombinasikan studi literatur dan analisis data dari para ahli sebagai stakeholder objek penelitian. Hasil penelitian menunjukkan bahwa:

1. Terdapat 5 strategi yang memengaruhi perusahaan crowd business syariah sehingga mampu menghadapi peluang dan tantangan bisnisnya. Kelima strategi yang termasuk ke dalam institutional capital perusahaan ini adalah crowd business equity base, product and content sales, technology and buyer fulfillment, kualitas dan kuantitas promotor, dan reputation and quality control.

2. Terdapat 5 strategi penentu keunggulan kompetitif dari perusahaan crowd business syariah yang termasuk ke dalam resource capital perusahaan, antara lain company image, leadership, distribution system, promotor training system, dan product innovation.

3. Ditemukan 3 strategi kinerja yang harus menjadi prioritas untuk mencapai keunggulan kompetitif yang berkelanjutan pada crowd business syariah dengan paparan sebagai berikut:

a. Resource capital merupakan competitive advantage crowd business syariah yang berarti harus menjadi prioritas utama.

b. Efektivitas kinerja perlu menjadi benchmark (nilai acuan) dalam menentukan alternatif strategi manajemen.

c. Prioritas strategi company image dengan menguatkan branding crowd business syariah.

Dengan kata lain, HNI perlu memperhatikan strategi kinerja crowd business syariah yaitu meningkatkan competitive advantage dalam dengan memaksimalkan resource capital khususnya kinerja company image. Selain itu, tujuan efektivitas manajemen masih perlu direalisasikan lebih matang untuk menjadikan HNI sebuah crowd business syariah yang berdaya saing di masa depan.

\section{Saran}

Beberapa saran yang dapat penulis kemukakan sehubungan dengan penemuan hasil penelitian ini terhadap perumusan masalah adalah:

1. HNI perlu merevitalisasi kembali posisi kompetitifnya sebagai market leader dengan mengevaluasi dan meningkatkan kinerja kategori modal resource secara keseluruhan dalam menciptakan competitive advantage terutama company image.

2. HNI sebagai crowd business syariah yang memiliki tujuan jangka panjang sebagai sebuah entitas yang dapat menjadi kendaraan Muslim crowd untuk membangun kesejahteraan dan kejayaan perekonomian Islam kembali, HNI perlu memperhatikan manajemen efektif empat kali dari manajemen efisien. 
3. HNI sebagai halal network perlu memperhatikan strategi company image sebagai tiga prioritas utama untuk meningkatkan sustainable competitive advantage dengan menggencarkan branding HNI dalam meminimalisir anggapan negatif tentang MLM pada HNI, serta mengemas lebih friendly user dalam proses delivering konten produk HNI yang unggul dan unik. Selain itu, menjadikan effective strategy sebagai benchmark dalam meningkatkan marketing dan networking capabilities HNI.

\section{DAFTAR PUSTAKA}

Achsien, I. H. \& Purnamasari, D. L. (2016). Islamic crowd-funding as the next financial innovation in Islamic finance: Potential and anticipated regulation in Indonesia. European Journal of Islamic Finance, (5), 14-23.

Ahmad, F. S., Omar, R., Rasid, S. Z. A., \& Amin, M. (2012). Leadership branding for sustainable customer engagement. International Journal Economics and Management Engineering, 6(2), 209-216.

Ali, M. F., Bashar, A. \& Shah, A. (2015, April). Smartcrowd: novel approach to big crowd management using mobile cloud computing. In 2015 International Conference on Cloud Computing (ICCC) (pp. 1-4). IEEE.

Anam. (2020). Chairul Tanjung: Tularkan semangat interpreneurship kepada peserta KUII VII di Pangkal Pinang [Internet]. [diakses 2020 Oct 15]. Tersedia pada: https://mui.or.id/berita/27582/chairul-tanjung-tularkan-semangat-interpreneurship-kepada-peser ta-kuii-vii/.

Arshad, R., Noor, A. H. M. \& Yahya, A. (2015). Human capital and Islamic-based social impact model: Small enterprise perspective. Procedia Economics and Finance, 31, 510-519.

Boudreau, K. J. \& Lakhani, K. R. (2013). Using the crowd as an innovation partner. Harvard Business Review, 91(4), 60-69.

Chesbrough, H. (2003). Open innovation: How companies actually do it. Harvard Business Review, 81(7): 12-14.

David, F. R. \& David, F. R. (2016). Strategic Management: A Competitive Advantage Approach, Concepts and Cases. New York (US), Pearson.

Dawson, R. \& Bynghall, S. (2012). Getting Results from Crowds. San Francisco (US), Advanced Human Technologies.

Firly, R. Z. (2017). Dwilogi the Master Book to be the Best Market Leader. Hand Book for Agents of Halal Network International. Jakarta (ID), CELLS - HNI.

Gallant, M. R. (2009). Sustainable Development: A Challenge to Muslim Countries. (Doctoral Dissertation, University of Kwazulu-Natal, Durban, South Africa).

Hafeez, K., Zhang, Y. \& Malak, N. (2002). Core competence for sustainable competitive advantage: a structured methodology for identifying core competence. IEEE Transactions on Engineering Management. 49(1), 28-35.

Haseeb, M., Hussain, H. I., Kot, S., Androniceanu, A. \& Jermsittiparsert, K. (2019). Role of social and technological challenges in achieving a sustainable competitive advantage and sustainable business performance. Sustainability, 11(14), 1045-1068.

Henkel, J. (2006). Selective revealing in open innovation processes: The case of embedded Linux. Research Policy, 35(7), 953-969.

Hoque, N., Ali, M. H., Arefeen, S., Mowla, M. M., \& Mamun, A. (2018). Use of crowdfunding for developing social enterprises: An Islamic approach. International Journal of Business and Management, 13(6), 156-164.

Hussin, R., Hassan, F., \&Yusoff, S. H. (2017). Guest editors: Da'wah in the media for Muslims' sustainability. Abqari Journal, 12(1), 7-10.

Keong, L. S. \& Dastane, O. (2019). Building a sustainable competitive advantage for Multi-Level Marketing (MLM) firms: An empirical investigation of contributing factors. Journal of Distribution Science, 8(1), 5-11. 
Komara, D. (2016). Awas begundal money game. APLI Network News, 4.

Komara, D. (2017). Follow up, resep sukses networker. APLI Network News, 5.

Lüttgens, D., Pollok, P., Antons, D. \& Piller, F. (2014). Wisdom of the crowd and capabilities of a few: internal success factors of crowdsourcing for innovation. Journal of Business Economics, 84(3), 339-374.

Magretta, J. (2002). Why business models matter. Harvard Business Review, 80, 86-92.

Marjanovic, S., Fry, C. \& Chataway, J. (2012). Crowdsourcing based business models: In search of evidence for innovation 2.0. Science and Public Policy, 39(3), 318-332.

Markides, C. \& Charitou, C. D. (2004). Competing with dual business models: A contingency approach. Academy of Management Perspectives, 18(3), 22-36.

Mirahmadi, S., Attafar, A. \& Ketabi, S. (2018). Developing a fuzzy ANP model for performance appraisal based on firm strategy. Decision Science Letters, 7(3), 243-256.

Morioka, S. N., Bolis, I., Evans, S., \& Carvalho, M. M. (2017). Transforming sustainability challenges into competitive advantage: Multiple case studies kaleidoscope converging into sustainable business models. Journal of Cleaner Production, 167, 723-738.

Mukerjee, K. (2016). Factors that contribute towards competitive advantage: A conceptual analysis. IUP Journal of Business Strategy, 13(1), 26-39.

Oliver, C. (1997). Sustainable competitive advantage: Combining institutional and resource-based views. Strategic Management Journal, 18(9), 697-713.

Omer, S. (2014). Sustainability and Islamic Architecture [Internet]. [diakses 2020 Oct 15]. Tersedia pada: https://medinanet.org/2014/10/sustainability-and-islamic-architecture/.

Saaty, T. L. (1999, August). Fundamentals of the analytic network process. In Proceedings of the 5th international symposium on the analytic hierarchy process (pp. 12-14).

Sarif, S. M. (2019). Strategic ta'awun and fastabiqul khairat partnerships for sustainable competitive advantage among small and medium enterprises in the Muslim world. Asian Academy of Management Journal, 24(1), 125-139.

Sumarwan, U. (2017). Pemasaran Strategik: Perspektif Perilaku Konsumen dan Marketing Plan. Bogor (ID), IPB Press.

Swasono, S.E. (2005). Kebersamaan dan Asas Kekeluargaan (Mutualism \& Brotherhood). Jakarta(ID), UNJ Press.

Vorhies, D. W. \& Morgan, N. A. (2005). Benchmarking marketing capabilities for sustainable competitive advantage. Journal of Marketing, 69(1), 80-94.

World Population Review. (2020). Muslim Population by Country 2020 [Internet]. [diakses 2020 Oct 15]. Tersedia pada: https://worldpopulationreview.com/country-rankings/muslim-populationby-country.

Yarmunida, M. (2014). Eksistensi syirkah kontemporer. Jurnal Ilmiah Mizani: Wacana Hukum, Ekonomi dan Keagamaan, 1(2), 232-243.

Yüksel, İ. \& Dagdeviren, M. (2007). Using the analytic network process (ANP) in a SWOT analysisA case study for a textile firm. Information Sciences, 177(16), 3364-3382.

Yusanto, M. I. \& Widjajakusuma, M. K. (2002). Menggagas Bisnis Islami. Jakarta (ID), Gema Insani Press. 